https://helda.helsinki.fi

\title{
Cyanolichens: An Evolutionary Overview
}

\section{Rikkinen, Jouko}

Kluwer Academic

2002

Rikkinen , J 2002 , Cyanolichens: An Evolutionary Overview . in A Rai , B Bergman \& U

Rasmussen (eds), Cyanobacteria in Symbiosis . Kluwer Academic , pp. 31-72 .

http://hdl.handle.net/10138/310131

unspecified

acceptedVersion

Downloaded from Helda, University of Helsinki institutional repository.

This is an electronic reprint of the original article.

This reprint may differ from the original in pagination and typographic detail.

Please cite the original version. 


\title{
CYANOLICHENS: AN EVOLUTIONARY OVERVIEW
}

\author{
JOUKO RIKKINEN \\ Department of Applied Biology, P.O. Box 27, FIN-00014 University of Helsinki, Finland
}

\section{INTRODUCTION}

Lichens are self-supporting and ecologically obligate associations between symbiotic fungi and green algae and/or cyanobacteria. The term 'cyanolichen' refers to all lichens with cyanobacterial symbionts, either as the sole photosynthetic component or as the second photobiont in addition to the primary photobiont (eukaryotic algae). Lichen symbioses represent a major way of life among the Fungi. Almost one-fifth of all known fungal species are lichen-forming and within the Ascomycota about two-fifths of known species are lichenized. The morphological and physiological characteristics of these associations are highly specialized and often involve intricate connections between the symbionts. As lichens include primary as well as secondary producers, and have their own carbon cycles, they resemble miniature ecosystems rather than individuals or populations. The symbiotic nature of these systems is not limited to the thallus level biology of individual lichen species. Symbiotic processes also shape the structure of lichen communities on a global scale.

\section{DIVERSITY OF FUNGAL-CYANOBACTERIAL ASSOCIATIONS}

Lichens are a biological phenomenon, not just a systematic group. Lichens do not have independent scientific names; all symbiotic partners have their own separate names and the name of intact 'lichen' refers to the dominating fungal partner alone. Many different types of fungi associate with cyanobacteria. These cyanophilous species, like all fungi, depend on nutrients contained in or released by other organisms. The nutritional requirements of many fungi are satisfied in the finely tuned symbioses, of which cyanolichens provide some outstanding examples. However, while cyanolichens are often quoted as premier examples of mutualism between prokaryotic and eukaryotic organisms, there is no reason to believe that anything but a continuous cline would exist between parasitic and mutualistic interactions in these symbioses.

Molecular studies have clearly shown that lichen-like symbioses have independently arisen on several occasions (Gargas et al., 1995; Tehler et al., 2000; Lutzoni et al., 2001). This partly explains the present diversity of lichens and the mixed occurrences of lichenized and non-lichenized species in many fungal groups. Aptroot (1998) estimated that there would have been as many as 100 lichenization events, involving re- and de-lichenization, during the diversification of extant Fungi. Some molecular evidence suggests that the gains of lichenization have been infrequent during evolution and there may have been several independent losses of the lichen symbiosis in different ascomycete lineages (Kranner and Lutzoni, 1999; Lutzoni et al., 2001). As a consequence, some lineages of exclusively non-lichen-forming fungi may have evolved form lichen-forming ancestors (Lutzoni et al., 2001). 
In order to demonstrate the diversity of extant fungal-cyanobacterial relationships an attempt was made to collect them all into a single list (Table 1). The list is not complete, but includes a vast majority of presently known mutualistic, commensalistic and parasitic interactions between cyanobacteria and fungi. For reasons of space the list could not be annotated. The interested reader is first referred to the Ainsworth \& Bisby's Dictionary of the Fungi (Hawksworth et al., 1995). For extensive lists of lichenological literature one can consult the The Bryologist's Recent Literature Lists, presently on-line at http://www.toyen.uio.no/botanisk/bot-mus/lav/sok_rll.htm.

\subsection{Mycobionts of Cyanolichens}

Cyanobacteria form lichen symbioses almost exclusively with Ascomycota. Depending on the taxonomic classification used, 15-18 orders of ascomycetes include lichen-forming taxa (Table 1). Most of these include both lichenized and non-lichenized species and only a few groups are exclusively lichenized. Molecular data are rapidly adding to a new understanding of the phylogenetic relationships between different ascomycete groups, including those with lichenized species. However, as most ascomycete genera have yet to have any of their species sequenced, the current classification is clearly a system in transition (Hawksworth et al., 1995; Alexopoulos et al., 1996; Tehler et al., 2000).

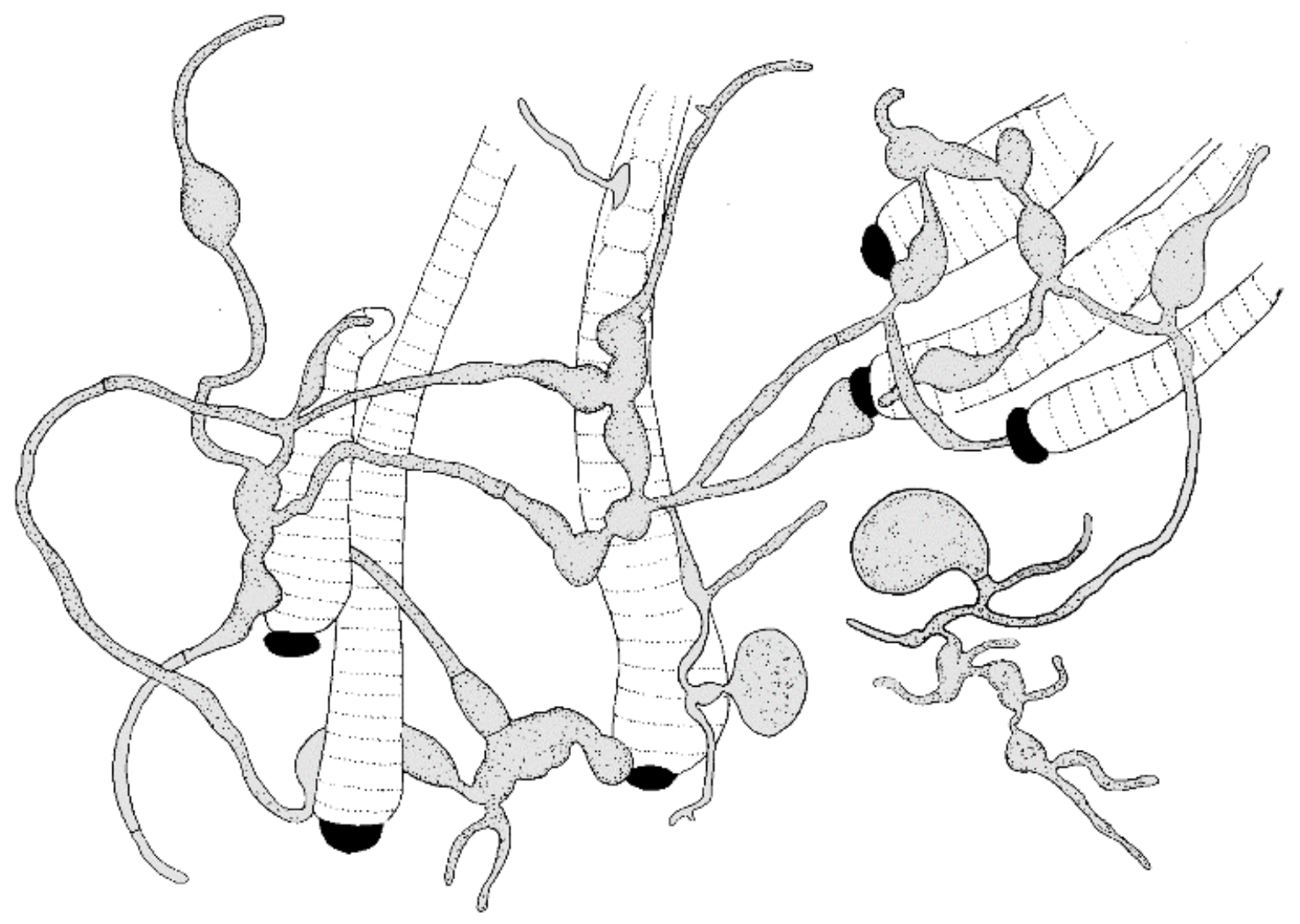

Figure 1. Polycentric chytrid feeding on filamentous cyanobacteria (after Karling, 1977). 
Many zygomycetes and basidiomycetes enter into mycorrhizal symbioses, but mutualistic or parasitic associations between these types of fungi and cyanobacteria appear to be rare (Table 1). The phylum Chytridiomycota includes mainly obligate parasites. Symbiotic forms are only known from animal guts, where anaerobic rumen chytrids take part in the digestive processes of herbivores. Some aquatic chytrids are known to feed on filamentous cyanobacteria (Fig. 1). For example, different species of Rhizophydium have been recorded from Anabaena, Aphanizomenon, Calothrix, Dichothrix, Lyngbya, and Oscillatoria (Table 1). In addition to true fungi, some oomycetes (Oomycota) also live on free-living cyanobacteria (e.g., Lagenidium on Lyngbya and Syzygangia on Tolypothrix). However, none of these organisms have yet been recorded from lichen thalli (Sparrow, 1960; Karling, 1977).

\subsubsection{Primary Mycobionts}

Some 13500 species of lichen-forming ascomycetes are presently known (Hawksworth et al., 1995). Cyanotrophic and lichenicolous taxa are found in many different ascomycete groups, including several pyrenocarpous orders. Lichenforming species occur in about 50 families and 130 genera, most of which belong to two apothecial orders: Lecanorales and Lichinales. Approximately 1550 species of cyanolichens are presently known. Thus, roughly $12 \%$ of all lichen-forming fungi are associated with cyanobacteria (Table 1).

Lecanorales is one of the largest ascomycete orders. Most species in the group are lichen-forming and most lichenicolous forms appear to have evolved from lichenized ancestors (Hawksworth et al., 1995, Rambold and Triebel, 1992; Lutzoni et al., 2001). Overall, however, a large majority of lecanoralean lichens are green algal and only a minority house cyanobacteria as primary or accessory symbionts. The order includes foliose and fruticose macrolichens as well as many crustose species. Ascomata are typically apothecial, flat to cup-shaped, and usually with active ascospore dispersal from thick-walled asci. The anamorphs are pycnidial. In general, the multi-layered ascus wall and a more or less developed amyloid structure in the ascus apex characterize members of Lecanorales. However, molecular data also indicate large monophyletic groups within the order (Rambold and Triebel, 1992; Dellemère, 1994; Haffellner et al., 1994; Hawksworth et al., 1995; Tehler, 1996; Tehler et al., 2000; Lutzoni et al., 2001). Depending on the taxonomic classification used, the order Lecanorales includes some 40 families and well over 300 genera. The circumscription and placement of many groups still remain uncertain. Cyanophilous species occur in ca. 25 families and nearly 80 genera (Table 1).

Lecanoralean cyanolichens are found in many types of environments ranging from open tundra to rainforests. However, most species thrive in habitats that combine moderate light intensities with a relatively high atmospheric humidity. Because of their ability to utilize low photon flux densities and wavelengths of light that have filtered through a vascular plant canopy, many cyanolichens are well adopted to live in shady forest habitats (Rikkinen, 1995). Epiphytic communities rich in cyanolichen species are remarkably similar in composition over the whole circumpolar belt of boreal coniferous forests and the adjoining areas of mixed coniferous-deciduous forest. 
Table 1. Fungal-cyanobacterial interactions. Most known fungi involved in lichen-like symbioses with cyanobacteria, as well as parasitic or commensalistic interactions are listed. The identity of the lichen cyanobiont or an example of the host cyanolichens is given. The last column gives a rough estimate of the number of cyanophilic species in each genus. Note that some genera also contain species that do not associate with cyanobacteria.

\begin{tabular}{lllll}
\hline Fungal group & Host & Interaction type & Thallus morphology & $\#$ \\
\hline
\end{tabular}

\section{CHYTRIDIOMYCOTA}

\section{Blastocladiales \\ Blastocladiaceae Blastocladiella Inc. sed. Rhizosiphon

Nostoc

Chroococcidiopsis?

Endocyanosis

Indeterminate

Fossil bipartite lichen Foliose

Indeterminate

Indeterminate

Indeterminate

Indeterminate

Indeterminate

Parasitic fungus

Parasitic fungus

Indeterminate

Inc. sed

Geosiphon

Winfrenatia?

\section{BASIDIOMYCOTA}

\section{Agaricales}

Tricholomataceae

Fayodia

Omphalina

Rickenella

Aphyllophorales

Corticiaceae

Acantholichen

Meruliaceae

Dictyonema

Tremellales

Tremellaceae

Tremella

\section{Peltigera \\ Peltigera}

Nostoc?

Scytonema

Scytonema

Lobaria

Lichenicolous fungus

Indeterminate

Bipartite lichen

Foliose

Bipartite lichen

Indeterminate

1

5

Lichenicolous fungus Indeterminate

\section{ASCOMYCOTA}

Agyriales

$$
\begin{gathered}
\text { Agyriaceae } \\
\text { Placopsis }
\end{gathered}
$$

Arthoniales

Arthoniaceae Arthonia

Roccellaceae Plectocarpon Opegrapha

Diaporthales

Valsaceae Obryzum

Dothideales s. lat. Chaeotothyriales Biciliopsis Dacampiaceae
Nostoc etc.

Tripartite lichen

Foliose

C. 55

Peltigera

Nephroma

Peltigera

Leptogium

Leptogium
Lichenicolous fungus Indeterminate

Lichenicolous fungus Indeterminate Lichenicolous fungus Indeterminate

1

Lichenicolous fungus Indeterminate 1

Lichenicolous fungus Indeterminate
1

3

2

1
1

1

1 


\begin{tabular}{|c|c|c|c|c|}
\hline Dacampia & Peltigera & Lichenicolous fungus & Indeterminate & 2 \\
\hline Polycoccum & Peltigera & Lichenicolous fungus & Indeterminate & 7 \\
\hline Pyrenidium & Peltigera & Lichenicolous fungus & Indeterminate & 2 \\
\hline \multicolumn{5}{|l|}{ Herpotrichiellaceae } \\
\hline Capronia & Peltigera & Lichenicolous fungus & Indeterminate & 1 \\
\hline \multicolumn{5}{|l|}{ Hysteriaceae } \\
\hline Hemigrapha & Peltigera & Lichenicolous fungus & Indeterminate & 1 \\
\hline \multicolumn{5}{|l|}{ Leptosphaeriaceae } \\
\hline Leptosphaeria & Peltigera & Lichenicolous fungus & Indeterminate & 1 \\
\hline \multicolumn{5}{|l|}{ Microthyriaceae } \\
\hline Lichenopeltella & Peltigera & Lichenicolous fungus & Indeterminate & 7 \\
\hline \multicolumn{5}{|l|}{ Mycosphaerellaceae } \\
\hline Sphaerulina & Collema & Lichenicolous fungus & Indeterminate & 1 \\
\hline Stigmidium & Peltigera & Lichenicolous fungus & Indeterminate & 6 \\
\hline \multicolumn{5}{|l|}{ Pleosporaceae } \\
\hline Pleospora & Solorina & Lichenicolous fungus & Indeterminate & 1 \\
\hline Leptosphaerulina & Peltigera & Lichenicolous fungus & Indeterminate & 1 \\
\hline \multicolumn{5}{|l|}{ Pyrenothricaceae } \\
\hline Pyrenothrix & Scytonema & Parasitic fungus & Indeterminate & 1 \\
\hline Cyanoporina & Cyanobacterium & Parasitic fungus & Indeterminate & 1 \\
\hline \multicolumn{5}{|l|}{ Pseudoperisporiaceae } \\
\hline Myxophora & Scytonema & Parasitic fungus & Indeterminate & 1 \\
\hline Wentiomyces & Peltigera & Lichenicolous fungus & Indeterminate & 1 \\
\hline \multicolumn{5}{|l|}{ Inc. sed. } \\
\hline 'Arthopyrenia' & Chroococcales & Bipartite lichen? & Indeterminate & 1 \\
\hline Cercidospora & Peltigera & Lichenicolous fungus & Indeterminate & 4 \\
\hline Collemopsidium & Xanthocapsa & Bipartite lichen? & Indeterminate & 3 \\
\hline 'Didymella' & Zahlbrucknerella & Lichenicolous fungus & Indeterminate & 1 \\
\hline Didymellopsis & Collema & Lichenicolous fungus & Indeterminate & 4 \\
\hline Endococcus & Collema & Lichenicolous fungus & Indeterminate & 3 \\
\hline Phycorella & Scytonema & Parasitic fungus & Indeterminate & 1 \\
\hline Thelenidia & Cyanobacterium & Bipartite lichen? & Indeterminate & 1 \\
\hline Zwackhiomyces & Peltigera & Lichenicolous fungus & Indeterminate & 3 \\
\hline \multicolumn{5}{|l|}{ Erysiphales } \\
\hline \multicolumn{5}{|l|}{ Erysiphaceae } \\
\hline Phyllactinia & Peltigera & Lichenicolous fungus & Indeterminate & 1 \\
\hline \multicolumn{5}{|l|}{ Hypocreales } \\
\hline \multicolumn{5}{|l|}{ Hypocreaceae } \\
\hline Nectria & Peltigera & Lichenicolous fungus & Indeterminate & 1 \\
\hline Nectriopsis & Coccocarpia & Lichenicolous fungus & Indeterminate & 3 \\
\hline Paranectria & Peltigera & Lichenicolous fungus & Indeterminate & 1 \\
\hline Pronectria & Peltigera & Lichenicolous fungus & Indeterminate & 4 \\
\hline Xenonectriella & Collema & Lichenicolous fungus & Indeterminate & 1 \\
\hline Niessliaceae & & & & \\
\hline Niesslia & Lobaria & Lichenicolous fungus & Indeterminate & 1 \\
\hline canorales & & & & \\
\hline Acarosporaceae & & & & \\
\hline Sarcosagium & Peltigera & Lichenicolous lichen & Indeterminate & 1 \\
\hline Thelocarpon & Peltigera & Lichenicolous lichen & Indeterminate & 2 \\
\hline Arctomiaceae & & & & \\
\hline Arctomia & Nostoc & Bipartite lichen & Crustose & 2 \\
\hline Wawea & Nostoc & Bipartite lichen & Fruticose & 1 \\
\hline Bacidiaceae & & & & \\
\hline Bacidia & Peltigera & Lichenicolous lichen & Crustose & 3 \\
\hline Compsocladium & Scytonema & Tripartite lichen & Fruticose & 1 \\
\hline Szczawinskia & Stigonema & Tripartite lichen & Crustose & 1 \\
\hline Biatoraceae & & & & \\
\hline Toninia & $\begin{array}{l}\text { Stigonema, } \\
\text { Gloeocapsa }\end{array}$ & Lichenicolous lichen & Crustose & c. 40 \\
\hline Brigantiaeaceae & & & & \\
\hline Argopsis & Nostoc etc. & Tripartite lichen & Fruticose & 3 \\
\hline Candelariaceae & & & & \\
\hline Candellariella & Stigonema etc. & Cyanotrophic lichen & Crustose & 4 \\
\hline Catillariaceae & & & & \\
\hline Catillaria & Peltigera & Lichenicolous lichen & Crustose & 1 \\
\hline Halecania & Stigonema etc. & Cyanotrophic lichen & Crustose & 1 \\
\hline Cladoniaceae & & & & \\
\hline Pilophorus & Nostoc etc. & Tripartite lichen & Fruticose & 11 \\
\hline
\end{tabular}




\begin{tabular}{|c|c|c|c|c|}
\hline Coccocarpia & Scytonema & Bipartite lichen & Foliose & 20 \\
\hline Peltularia & Scytonema etc. & Bipartite lichen & Foliose & 3 \\
\hline Spilonema & Stigonema etc. & Bipartite lichen & Fruticose & 4 \\
\hline Spilonemella & Scytonema & Bipartite lichen & Crustose & 2 \\
\hline Steinera & Nostoc etc. & Bipartite lichen & Crustose & 4 \\
\hline \multicolumn{5}{|l|}{ Collemataceae } \\
\hline Collema & Nostoc & Bipartite lichen & Foliose & c. 75 \\
\hline Homothecium & Nostoc & Bipartite lichen & Foliose & 5 \\
\hline Leciophysma & Nostoc & Bipartite lichen & Fruticose & 2 \\
\hline Leightoniella & Nostoc & Bipartite lichen & Foliose & 1 \\
\hline Leptogium & Nostoc & Bipartite lichen & Foliose & c. 160 \\
\hline Physma & Nostoc & Bipartite lichen & Foliose & c. 10 \\
\hline Ramalodium & Nostoc & Bipartite lichen & Foliose & 4 \\
\hline Staurolemma & Nostoc & Bipartite lichen & Foliose & 4 \\
\hline \multicolumn{5}{|l|}{ Ectolechiaceae } \\
\hline Calopadia & Scytonema & Tripartite lichen & Crustose & 1 \\
\hline Lasioloma & Scytonema & Tripartite lichen & Crustose & 3 \\
\hline 'Lopadium' & Scytonema & Tripartite lichen & Crustose & 1 \\
\hline \multicolumn{5}{|l|}{ Heppiaceae } \\
\hline Corynecystis & Cyanobacterium & Bipartite lichen & Foliose & 1 \\
\hline Epiphloea & Nostoc & Bipartite lichen & Foliose & 1 \\
\hline Heppia & Scytonema & Bipartite lichen & Foliose & 6 \\
\hline \multicolumn{5}{|l|}{ Lecanoraceae } \\
\hline Bryodina & Stigonema & Cyanotrophic lichen & Crustose & 3 \\
\hline Carbonea & Gloeocapsa & Cyanotrophic lichen & Crustose & 2 \\
\hline Glyphopeltis & Peltula & Lichenicolous lichen & Crustose & 1 \\
\hline Lecanora & Stigonema etc. & Cyanotrophic lichen & Crustose & 5 \\
\hline Miriquidica & Stigonema etc. & Cyanotrophic lichen & Crustose & 4 \\
\hline \multicolumn{5}{|l|}{ Lobariaceae } \\
\hline Lobaria & Nostoc & $\mathrm{Bi}$ - / tripartite lichen & Foliose & c. 60 \\
\hline Pseudocyphellaria & Nostoc & $\mathrm{Bi}$ - / tripartite lichen & Foliose & c. 115 \\
\hline Sticta & Nostoc & $\mathrm{Bi}$ - / tripartite lichen & Foliose & c. 200 \\
\hline 'Dendriscocaulon' & Nostoc & Bipartite lichen & Fruticose & c. 10 \\
\hline \multicolumn{5}{|l|}{ Nephromataceae } \\
\hline Nephroma & Nostoc & $\mathrm{Bi}$ - / tripartite lichen & Foliose & c. 35 \\
\hline \multicolumn{5}{|l|}{ Micareaceae } \\
\hline Micarea & Stigonema etc. & Cyanotrophic lichen & Crustose & 3 \\
\hline Scutula & Peltigera & Lichenicolous fungus & Crustose & c. 10 \\
\hline \multicolumn{5}{|l|}{ Pannariaceae } \\
\hline Degelia & Scytonema & Bipartite lichen & Foliose & c. 10 \\
\hline Erioderma & Scytonema & Bipartite lichen & Foliose & 16 \\
\hline Fuscoderma & Nostoc & Bipartite lichen & Foliose & 3 \\
\hline Fuscopannaria & Nostoc & Bipartite lichen & Foliose & c. 30 \\
\hline Hosseusia & Cyanobacterium & Bipartite lichen & Foliose & 1 \\
\hline Leioderma & Scytonema & Bipartite lichen & Foliose & 5 \\
\hline Moelleropsis & Nostoc & Bipartite lichen & Crustose & 2 \\
\hline Pannaria & Nostoc & Bipartite lichen & Foliose & 12 \\
\hline Parmeliella & Nostoc & Bipartite lichen & Foliose & c. 40 \\
\hline Protopannaria & Nostoc & Bipartite lichen & Foliose & 1 \\
\hline Psoroma & Nostoc & $\mathrm{Bi}$ - / tripartite lichen & Foliose & c. 50 \\
\hline Psoromidium & Nostoc & Tripartite lichen & Crustose & 2 \\
\hline Santessoniella & Nostoc & Bipartite lichen & Crustose & 9 \\
\hline Siphulastrum & Scytonema & Bipartite lichen & Foliose & 4 \\
\hline \multicolumn{5}{|l|}{ Placynthiaceae } \\
\hline Hertella & Tolypothrix etc. & Bipartite lichen & Fruticose & 2 \\
\hline Koerberia & Scytonema & Bipartite lichen & Foliose & 2 \\
\hline Leptochidium & Scytonema & Bipartite lichen & Foliose & 1 \\
\hline Placynthiopsis & Cyanobacterium & Bipartite lichen & Crustose & 1 \\
\hline Placynthium & Dichothrix etc. & Bipartite lichen & Crustose & 25 \\
\hline Polychidium & Nostoc etc. & Bipartite lichen & Fruticose & 5 \\
\hline Vestergrenopsis & Scytonema & Bipartite lichen & Foliose & 2 \\
\hline \multicolumn{5}{|l|}{ Peltigeraceae } \\
\hline Massalongia & Nostoc & Bipartite lichen & Foliose & 3 \\
\hline Peltigera & Nostoc & $\mathrm{Bi}$ - / tripartite lichen & Foliose & c. 60 \\
\hline Solorina & Nostoc & Tripartite lichen & Foliose & 10 \\
\hline
\end{tabular}




\begin{tabular}{|c|c|c|c|c|}
\hline \multicolumn{5}{|l|}{ Physciaceae } \\
\hline Rinodina & Stigonema etc. & Cyanotrophic lichen & Crustose & 6 \\
\hline \multicolumn{5}{|l|}{ Porpidiaceae } \\
\hline Amygdalaria & Stigonema etc. & Tripartite lichen & Crustose & 3 \\
\hline \multicolumn{5}{|l|}{ Psoraceae } \\
\hline Psorula & Stigonema & Cyanotrophic lichen & Crustose & 1 \\
\hline \multicolumn{5}{|l|}{ Sphaerophoraceae } \\
\hline Sphaerophorus & Scytonema & Tripartite lichen & Fruticose & 2 \\
\hline \multicolumn{5}{|l|}{ Stereocaulaceae } \\
\hline Muhria & Stigonema & Tripartite lichen & Crustose & 1 \\
\hline Stereocaulon & $\begin{array}{l}\text { Nostoc, Scytonema, } \\
\text { Stigonema }\end{array}$ & Tripartite lichen & Fruticose & c. 125 \\
\hline \multicolumn{5}{|l|}{ Teloschistaceae } \\
\hline Caloplaca & Stigonema & Cyanotrophic lichen & Crustose & 1 \\
\hline \multicolumn{5}{|l|}{ Vezdaeaceae } \\
\hline Vezdaea & Peltigera & Lichenicolous lichen & Crustose & 2 \\
\hline \multicolumn{5}{|l|}{ Inc. sed. } \\
\hline Corticifraga & Peltigera & Lichenicolous fungus & Indeterminate & 2 \\
\hline Corticiruptor & Sticta & Lichenicolous fungus & Indeterminate & 1 \\
\hline \multicolumn{5}{|l|}{ Leotiales } \\
\hline \multicolumn{5}{|l|}{ Dermateaceae } \\
\hline Mollisia & Collema & Lichenicolous fungus & Indeterminate & 1 \\
\hline \multicolumn{5}{|l|}{ Hyaloscyphaceae } \\
\hline Polydesmia & Peltigera & Lichenicolous fungus & Indeterminate & 1 \\
\hline \multicolumn{5}{|l|}{ Leotiaceae } \\
\hline Calycina & Peltigera & Lichenicolous fungus & Indeterminate & 2 \\
\hline Unguiculariopsis & Sticta & Lichenicolous fungus & Indeterminate & 2 \\
\hline \multicolumn{5}{|l|}{ Orbiliaceae } \\
\hline Orbilia & Peltigera & Lichenicolous fungus & Indeterminate & 1 \\
\hline Inc. sed. & & & & \\
\hline Skytella & Peltigera & Lichenicolous fungus & Indeterminate & 1 \\
\hline Lichinales & & & & \\
\hline Gloeoheppiaceae & & & & \\
\hline Gloeoheppia & Chroococcales & Bipartite lichen & Foliose & 4 \\
\hline Gudelia & Chroococcales & Bipartite lichen & Foliose & 1 \\
\hline Pseudopeltula & Chroococcales & Bipartite lichen & Foliose & 3 \\
\hline Lichinaceae & & & & \\
\hline Anema & Gloeocapsa & Bipartite lichen & Foliose & 7 \\
\hline Calotrichopsis & Calothrix & Bipartite lichen & Crustose & 3 \\
\hline Cryptothele & Gloeocapsa & Bipartite lichen & Crustose & 3 \\
\hline Digitothyrea & Chroococcales & Bipartite lichen & Fruticose & 3 \\
\hline Edwardiella & Gloeocapsa & Bipartite lichen & Indeterminate & 1 \\
\hline Ephebe & Stigonema & Bipartite lichen & Fruticose & 12 \\
\hline Euopsis & Gloeocapsa & Tripartite lichen & Crustose & 2 \\
\hline Finkia & Cyanobacterium & Bipartite lichen & Crustose & 1 \\
\hline Gyrocollema & Cyanobacterium & Bipartite lichen & Crustose & 1 \\
\hline Jenmania & Gloeocapsa & Bipartite lichen & Fruticose & 2 \\
\hline Lecidopyrenopsis & Gloeocapsa & Bipartite lichen & Crustose & 1 \\
\hline Lemmopsis & Cyanobacterium & Bipartite lichen & Crustose & 3 \\
\hline Lempholemma & Nostoc & Bipartite lichen & Foliose & c. 30 \\
\hline Leprocollema & Cyanobacterium & Bipartite lichen & Crustose & 3 \\
\hline Lichina & Calothrix etc. & Bipartite lichen & Crustose & 7 \\
\hline Lichinella & Chroococcidiopsis & Bipartite lichen & Fruticose & 11 \\
\hline Lichinodium & Scytonema & Bipartite lichen & Fruticose & 4 \\
\hline Mawsonia & Cyanobacterium & Bipartite lichen & Crustose & 1 \\
\hline Metamelanea & Chroococcales & Bipartite lichen & Fruticose & 3 \\
\hline Paulia & Chroococcales & Bipartite lichen & Foliose & 12 \\
\hline Peccania & Chroococcidiopsis & Bipartite lichen & Foliose & 4 \\
\hline Phloeopeccania & Gloeocapsa & Bipartite lichen & Foliose & 1 \\
\hline Phylliscidiopsis & Cyanobacterium & Bipartite lichen & Crustose & 1 \\
\hline Phylliscidium & Gloeocapsa & Bipartite lichen & Foliose & 1 \\
\hline Phyllisciella & Chroococcales & Bipartite lichen & Foliose & 3 \\
\hline Phylliscum & Chroococcales & Bipartite lichen & Foliose & 6 \\
\hline Porocyphus & Calothrix & Bipartite lichen & Foliose & 7 \\
\hline Psorotichia & Chroococcidiopsis & Bipartite lichen & Crustose & c. 50 \\
\hline Pterygiopsis & Chroococcales & Bipartite lichen & Crustose & c. 8 \\
\hline Pyrenocarpon & Chroococcales & Bipartite lichen & Crustose & 1 \\
\hline Pyrenopsis & Gloeocapsa etc. & Bipartite lichen & Crustose & c. 40 \\
\hline Stromatella & Chroococcales & Bipartite lichen & Fruticose & 1 \\
\hline
\end{tabular}




\begin{tabular}{|c|c|c|c|c|}
\hline Synalissa & Gloeocapsa & Bipartite lichen & Fruticose & 5 \\
\hline Thelignya & Calothrix & Bipartite lichen & Crustose & 1 \\
\hline Thermutis & Scytonema & Bipartite lichen & Fruticose & 1 \\
\hline Thermutopsis & Tolypothrix & Bipartite lichen & Fruticose & 1 \\
\hline Thyrea & Chroococcales & Bipartite lichen & Fruticose & c. 20 \\
\hline Zahlbrucknerella & Scytonema & Bipartite lichen & Fruticose & 7 \\
\hline \multicolumn{5}{|l|}{ Peltulaceae } \\
\hline Neoheppia & Chroococcales & Bipartite lichen & Foliose & 2 \\
\hline Peltula & Scytonema & Bipartite lichen & Foliose & c. 18 \\
\hline Phyllopeltula & Scytonema & Bipartite lichen & Foliose & 2 \\
\hline \multicolumn{5}{|l|}{ Ostropales } \\
\hline \multicolumn{5}{|l|}{ Stictidaceae } \\
\hline Nanostictis & Peltigera & Lichenicolous fungus & Indeterminate & 2 \\
\hline Petractis & Scytonema & Bipartite lichen & Crustose & 1 \\
\hline \multicolumn{5}{|l|}{ Patellariales } \\
\hline \multicolumn{5}{|l|}{ Arthrorhapidiaceae } \\
\hline Arthrorhapis & Pseudocyphellaria & Lichenicolous lichen & Crustose & 1 \\
\hline \multicolumn{5}{|l|}{ Pertusariales } \\
\hline \multicolumn{5}{|l|}{ Coccotremataceae } \\
\hline Coccotrema & Calothrix etc. & Tripartite lichen & Crustose & 9 \\
\hline \multicolumn{5}{|l|}{ Phyllacorales } \\
\hline Lichenochora & Fuscopannaria & Lichenicolous fungus & Indeterminate & 1 \\
\hline \multicolumn{5}{|l|}{ Pyrenulales } \\
\hline \multicolumn{5}{|l|}{ Pyrenulaceae } \\
\hline Cyanopyrenia & Cyanobacteria & Bipartite lichen & Crustose & 1 \\
\hline Pyrenocollema & Gleocapsa etc. & Bipartite lichen & Crustose & c. 20 \\
\hline \multicolumn{5}{|l|}{ Sordariales } \\
\hline \multicolumn{5}{|l|}{ Coniochaetaceae } \\
\hline Roselliniella & Peltigera & Lichenicolous fungus & Indeterminate & 5 \\
\hline Roselliniopsis & Placopsis & Lichenicolous fungus & Indeterminate & 1 \\
\hline Syanaptospora & Placopsis & Lichenicolous fungus & Indeterminate & 1 \\
\hline \multicolumn{5}{|l|}{ Nitschkiaceae } \\
\hline Acanthonitschkea & Peltigera & Lichenicolous fungus & Indeterminate & 1 \\
\hline Lasiosphaeriopsis & Stereocaulon & Lichenicolous fungus & Indeterminate & 2 \\
\hline Rhagadostoma & Peltigera & Lichenicolous fungus & Indeterminate & 1 \\
\hline \multicolumn{5}{|l|}{ Trichosphaeriales } \\
\hline \multicolumn{5}{|l|}{ Trichosphaeriaceae } \\
\hline Trichosphaeria & Peltigera & Lichenicolous fungus & Indeterminate & 1 \\
\hline Rhynchomeliola & Wawea & Lichenicolous fungus & Indeterminate & 1 \\
\hline \multicolumn{5}{|l|}{ Verrucariales } \\
\hline \multicolumn{5}{|l|}{ Verrucariaceae } \\
\hline Agonimia & Pseudocyphellaria & Lichenicolous lichen & Indeterminate & 1 \\
\hline Dermatocarpon & Collema & Lichenicolous lichen & Foliose & 1 \\
\hline Norrlinia & Peltigera & Lichenicolous fungus & Indeterminate & 1 \\
\hline Phaeospora & Peltigera & Lichenicolous fungus & Indeterminate & 1 \\
\hline Polyblastia & Peltigera & Lichenicolous fungus & Indeterminate & 1 \\
\hline Psoroglaena & Cyanobacterium & Bipartite lichen & Crustose & 3 \\
\hline Ascomycota (inc. sed.) & & & & \\
\hline Aphanopsidaceae & & & & \\
\hline Steinia & Peltigera & Lichenicolous lichen & Crustose & 1 \\
\hline Dactylosporaceae & & & & \\
\hline Dactylospora & Lobaria & Lichenicolous fungus & Crustose & 3 \\
\hline Melaspileaceae & & & & \\
\hline Melaspilea & Pseudocyphellaria & Lichenicolous fungus & Indeterminate & 1 \\
\hline Protothelenellaceae & & & & \\
\hline Protothelenella & Peltigera & Lichenicolous lichen & Crustose & 2 \\
\hline Genera (inc. sed.) & & & & \\
\hline Abrothallus & Nephroma & Lichenicolous fungus & Indeterminate & 3 \\
\hline Neolamya & Peltigera & Lichenicolous fungus & Indeterminate & 1 \\
\hline Pleosphaeria & Pyrenothrix & Parasitic fungus & Indeterminate & 1 \\
\hline
\end{tabular}

Examples of mitosporic genera that include lichenicolous species on cyanolichens: Dinemasporium, Diplodina, Epicoccum, Everniicola, Fusarium, Graphium, Hastifera, Hawksworthiana, Hobsonia, Illosporium, Karsteniomyces, Libertiella, Lichenoconium, Refractohilum, Talpapellis, Trichoconis, Phoma, Vagnia 
Lichinales includes three families and over 40 genera (Table 1). All species in this order are lichenized and nearly all of them associate with cyanobacteria (Henssen et al., 1987). Thalli are crustose, foliose or fruticose, and often gelatinous. Ascomata are apothecial, but may be perithecial in early stages, often immersed into the thallus. The asci are thin-walled and usually disintegrate at maturity releasing hyaline, non-septate spores. The anamorphs are pycnidial. Most species of Lichinales grow on rock or mineral soil. The group is well represented in humid coastal areas and at sites in dry regions where seepage water is periodically available. Many species are inconspicuous, but they can play important ecological roles in semi-arid ecosystems. Some species are dominant components of soil crusts in savannas, semi-deserts, deserts, and disturbed sites (Eldridge and Tozer, 1997; Schultz et al., 2000).

\subsubsection{Accessory Mycobionts and Cyanotrophic Fungi}

Many lichenicolous fungi live on or inside lichens as parasites, commensals or saprobes (Table 1). Foliose and fruticose macrolichens can harbour a great variety of filamentous fungi and yeasts (Petrini et al., 1990; Girlanda et al., 1997). However, common saprophytic moulds are comparatively scarce on living lichens and many of the lichenicolous fungi are exclusively lichenicolous. For example, Hawksworth and Miadlikowska (1997) listed 87 species of lichenicolous fungi from the genus Peltigera alone, of which 61 were not known from any other host. Also many other large cyanolichens are rich in lichenicolous species (Alstrup and Hawksworth, 1990; Kondratyuk and Galloway, 1995; Aptroot et al., 1997).

Even though lichenicolous fungi still remain a relatively undiscovered group of organisms (Hawksworth and Rossman, 1997), hundreds of species are already known. Many of them do not seem to cause major damage to their hosts. Most of them appear to exploit the photobionts of their host without direct nutritive exchange with the primary mycobiont (Fig. 2). Thus, the relationships between the fungal bionts are usually seen as commensalistic or antagonistic. However, in most cases this has not been experimentally demonstrated. Many lichenicolous fungi seem to have evolved from lichenized ancestors. The fungi continue to obtain carbohydrates from lichen symbioses without the need to find an appropriate free-living photobiont during each reproductive cycle (Rambold and Triebel, 1992; Lutzoni et al., 2001).

Lichenicolous lichens grow on other lichens, either as commensals or parasites (Table 1). In these associations the two lichen mycobionts have their own photobionts, whereas no additional photobionts occur in lichenicolous fungi (Fig. 2). Numerous green algal lichens can grow on cyanolichens. Many of them, like the Toninia species, start their development on cyanolichens, but later become independent (Rambold and Triebel, 1992). Conversely, there are very few cases of lichenicolous cyanolichens growing on green algal host lichens. One example involves the occurrences of Lichinodium sirosiphoideum on parmelioid macrolichens (Henssen,1963). Here, as in all multibiont associations, the exact relationship between cyanobacterial and green algal photobionts is not known. The mycobiont of the lichenicolous lichen appears to have a semi-antagonistic relationship with the host phycobiont, while the host mycobiont appears to have a semi-antagonistic or independent relationship with the cyanobiont of the lichenicolous lichen (Rambold and Triebel, 1992).

Some green algal lichens regularly associate with free-living cyanobacteria, usually Stigonema or Gloeocapsa, presumably in order to access an extra supply of nitrogen (Table 1). Such cyanotrophic associations may either be 
facultative or obligate (Poelt and Mayhofer, 1988). Rambold and Triebel (1992) viewed cyanotrophic behaviour as a compensating strategy of lichens that do not have symbiotic cyanobacteria as their primary photobionts or as additional symbionts in cephalodia. In many cyanotrophic associations the 'free-living' cyanobacteria are covered by dense mats of fungal hyphae. These compound structures have been called paracephalodia (Poelt and Mayhofer, 1988).
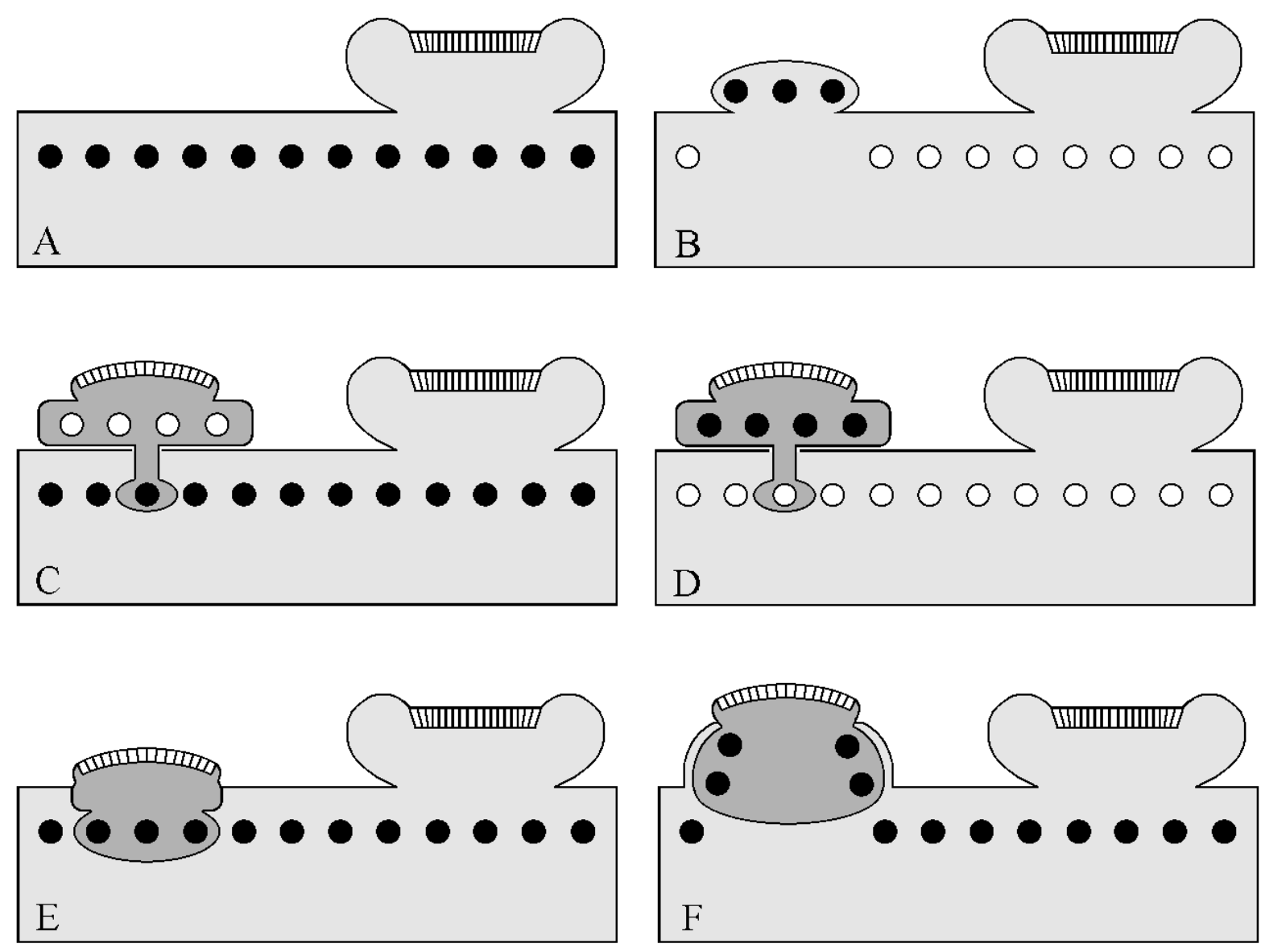

Figure 2. Examples of fungal-cyanobacterial associations: A. bipartite cyanolichen, B. tripartite (cephalodiate) cyanolichen, C. green algal lichenicolous lichen on cyanolichen, D. lichenicolous cyanolichen on green algal lichen, E. endokapylic lichenicolous fungus on cyanolichen, and F. gall-forming lichenicolous fungus on cyanolichen (after Rambold and Triebel, 1992).

In addition to the thallus-forming species, many filamentous ascomycetes obtain nutrients from free-living cyanobacteria without forming well-defined thalli (Table 1). Most of these fungi are pyrenocarpous ascomycetes, i.e., taxa with perithecium-like ascomata. The taxonomy of such fungi at family level and above remains unsettled (Hawksworth et al., 1995; Aptroot, 1998). 'Non-lichenized' cyanophilous fungi are very poorly known. The nature of their interactions may be difficult to assess, but many cyanophilous fungi do not seem to seriously harm their cyanobacterial hosts in culture. However, as almost nothing is presently known about specificity or stability in these interactions, and as many of the fungi live inside cyanobacterial colonies, they fit poorly into present definitions of a 
lichen. Somewhat similar symbioses are known to occur between some multicellular algae and endophytic marine fungi. Obligate associations of this type have been called mycophycobioses (Hawksworth, 1988).

\subsection{Photobionts of Cyanolichens}

The taxonomy of lichens is fully integrated into the classification of Fungi and most scientists working with lichens are essentially mycologists. In many lichen groups, therefore, photobiont characteristics have not been widely used in taxonomy. This partly explains why current knowledge of lichen photobionts is fragmentary at best. Serious attempts to determine the photobiont at a species or strain level have only been made for a small percentage of the lichen species. This refers not only to the photobionts of inconspicuous crustose lichens, but also to widespread and common macrolichens (Tschermak-Woess, 1988; Ahmadjian, 1993; Friedl and Büdel, 1996).

Many morphological and developmental features of lichen photobionts are not readily apparent in the symbiotic state. Often photobiont morphology is so drastically changed that even the generic position is revealed only by careful isolation and cultivation. The degree of modification varies among different photobionts and different lichen taxa, and it may depend on the age of the symbiotic tissue. Thus, the taxonomic identities of lichenized photobionts have been difficult or even impossible to determine, especially on intrageneric levels. While over thirty genera and 100 species of algae and cyanobacteria have been reported to occur as photobionts in lichens, many of the records have not been based on cultured material (Tschermak-Woess, 1988; Friedl and Büdel, 1996).

Recently the situation has greatly improved by the introduction of effective molecular methods for the identification of lichenized photobionts. These methods make it possible to identify photobionts within intact lichen thalli and offer great new tools for the study of photobiont biology. It has become clear that lichen mycobionts are strongly selective with respect to their photobionts. In many cases, only a few closely related photobiont strains serve as the appropriate symbiotic partner for individual mycobiont taxa. This indicates that the identification of photobionts will soon become a prerequisite in studies of lichen systematics (Miao et al., 1997; Rambold et al., 1998; Beck et al., 1998; Paulsrud and Lindblad, 1998; Paulsrud et al., 1998, 2000, 2001; Beck, 1999; Kroken and Taylor, 2000; Paulsrud, 2001; Lohtander, Oksanen, Paulsrud and Rikkinen, unpublished results).

\subsubsection{Cyanobionts}

Approximately 1700 species of fungi associate with different types of cyanobacteria (Table 1). As an adaptation to these interactions the cyanobacteria often undergo remarkable anatomical and physiological modifications (Rai et al., 2000). Thus, without the help of molecular methods, isolation and cultivation is often necessary for positive identification even at the generic level. Many lichen-forming cyanobacteria can be easily isolated and brought into unialgal culture (Ahmadjian, 1993). However, as lichen thalli commonly house a rich flora of epiphytic cyanobacteria, it is quite crucial to confirm that the isolated strains actually represent the symbionts within the corresponding lichen thalli.

The genus Nostoc is by far the most common cyanobiont in lichens, especially in the Lecanorales (Table 1). Strains of Nostoc are well known for their ability to enter into different types of symbioses, sometimes serving as a 
source of fixed carbon and nitrogen (as in bipartite cyanolichens), or strictly as a source of nitrogen (as in other symbioses). There is still controversy over the generic delimitation of Nostoc and several classification schemes with slightly different taxonomic concepts are currently in use (Geitler, 1932; Rippka et al., 1979; Kommarek and Anagnostidis, 1989; Castenhotz, 2001). All Nostoc spp. are filamentous and heterocystous, produce isopolar trichomes, lack branching, and their cells are cylindrical or spherical. Most of them posses a characteristic life cycle with distinct motile hormogonia and vegetative filaments showing different degrees of coiling. However, some lichenforming strains do not produce hormogonia under common growth conditions and they are thus very slow to spread on culture plates. The trichomes of these strains tend to occur in pearl-like colonies eventually giving rise to grape-like clusters. While the production of hormogonia is a diagnostic feature of Nostoc sensu Rippka et al. (1979), these nonmotile strains also fit well into the more classical circumscriptions of Nostoc (Paulsrud, 2001).

Several botanical names have been used for morphologically different strains of lichen-forming Nostoc. The cyanobionts of many cyanolichens, like various species of Peltigera, have been called Nostoc punctiforme (TschermakWoess, 1988). On the other hand, at least Nostoc commune, N. microscopicum, N. muscorum, N. punctiforme, and N. sphaericum have been identified as cyanobionts in different Collema species (Degelius, 1954). Nostoc punctiforme PCC73102 is a model strain for cyanobacterial symbioses, and most research on the physiology and molecular biology of symbiotic cyanobacteria have been done by using either this strain or its counterpart in the American Type Culture Collection, ATCC 29133 (Meeks et al., 1999). However, in recent inoculation experiments this strain was not incorporated into the tripartite lichen Peltigera aphthosa (Paulsrud et al., 2001). Clearly more research is needed before bacteriological or botanical species names can be used for different groups of lichen-forming Nostocs (Büdel, 1992; Friedl and Büdel, 1996).

The genetic diversity of Nostoc cyanobionts in many cyanolichens has been studied by using nucleotide sequences of the tRNA ${ }^{\text {Leu }}$ (UAA) intron as a genetic marker. Also 16S rDNA sequences have been used to resolve phylogenetic relationships (e.g., Paulsrud and Lindblad, 1998; Paulsrud, 2001; Rikkinen, Lohtander and Oksanen, unpublished results). These studies have confirmed that there is considerable genetic variation among lichen-forming Nostoc strains. The symbiotic strains group together with free-living Nostoc strains, forming a monophyletic group among the nostocalean cyanobacteria. The Nostoc clade is divided into several subgroups, one of which seems to only include symbiotic strains from epiphytic cyanolichens. Another group includes the cyanobionts of many terricolous cyanolichens, including Nostoc strains from other symbiotic systems (Lohtander, Oksanen and Rikkinen, unpublished results).

In addition to Nostoc, several other nostocalean genera also include lichen-forming taxa (Table 1). However, these cyanobionts have not yet been studied in detail. Scytonema, Calothrix and Dichothrix have been reported from a number of cyanolichens. Scytonema is also an important host for cyanophilous fungi. The stigonematalean cyanobacteria include some lichen-forming strains, most of which seem to belong to the genus Stigonema. These cyanobacteria evolve loose cyanotrophic associations with many cyanotrophic lichens (Tschermak-Woess, 1988; Friedl and Büdel, 1996).

The unicellular cyanobionts of lichens include genera that reproduce by binary fission (e.g.,Gloeocapsa) or by both binary and multiple fission (e.g., Chroococcidiopsis and Myxosarcina). Unfortunately these cyanobionts rarely 
show their specific mode of reproduction when lichenized. Strains of Gloeocapsa and Chroococcidiopsis appear to be the most important photobionts in the Lichinales. Within the Lecanorales Gloeocapsa forms loose associations with many green algal, cyanotrophic lichens (Table 1). Many other genera of unicellular cyanobacteria have been reported from lichens, but these records have not been based on cultured material (Tschermak-Woess, 1988; Friedl and Büdel, 1996).

\subsubsection{Phycobionts}

The primary photobionts in most tripartite lichens are coccoid green algae. However, the most widely distributed lichen phycobiont, Trebouxia, is rare in cyanolichens. The phycobionts of Stereocaulon and Pilophorus belong to this group and Dictyochloropsis, another genus of Trebouxiophyceae, is the green algal photobiont in tripartite species of Sticta and Lobaria (Tschermak-Woess, 1988, 1995; Friedl, 1995; Friedl and Büdel, 1996; Friedl and Rokitta, 1997; Rambold et al., 1998). As a whole, some 40 percent of all lichen-forming fungi associate with trebouxioid green algae. These phycobionts are particularly dominant in the in lichen floras of cool and temperate regions. Trentepohlia and related genera (Ulvophyceae) represent another major group of lichen phycobionts. These algae are particularly common in tropical and subtropical lichen floras. However, no associations between lichens with trentepohlioid phycobionts and cyanobacteria appear to have been reported, not even loose, cyanotrophic associations (Rikkinen, 1995; Rambold et al., 1998).

Coccomyxa is the primary phycobionts of tripartite Nephroma and Peltigera species (Tschermak-Woess, 1988; Vitikainen, 1994; Friedl and Büdel, 1996; Miadlikowska and Lutzoni, 2000). This alga reproduces exclusively by autospores and its exact taxonomic position thus remains unclear. We have studied genetic variation in phycobionts of five tripartite cyanolichens. The specimens had been collected from different geographical areas, including both European and North American sites. There was almost no variation among green algal ITS sequences from Nephroma arcticum, N. expallidum, Peltigera aphthosa, and P. leucophlebia. The phycobiont of $P$. britannica was more distinct, but when analysed with other green algae, it grouped together with the phycobionts of the other tripartite lichens. Thus, the deviating phycobiont may have been a different species or subspecies of Coccomyxa (Lohtander, Oksanen and Rikkinen, unpublished results). Comparable patterns of genetic diversity have been reported from the photobionts of some green algal lichens (Kroken and Taylor, 2000).

\subsection{Associated Organisms}

In addition to the functional components of lichen symbioses, many other organisms can live closely associated with cyanolichens. For example, heterotrophic bacteria are extremely abundant in the gelatinous sheaths of cyanobacteria, including those isolated from lichens (Ahmadjian, 1989). Nothing is presently known of the possible role of these bacteria in lichen symbioses. Naturally, all lichen bionts can also be hosts for still-smaller biological entities, such as viruses.

Large cyanolichens may often house a rich flora of epiphytic algae. Both diatoms and green algae are often seen and free-living cyanobacteria are quite common. Epiphytic diatoms are most frequent in relatively dry habitats, 
whereas green algae and cyanobacteria are often seen in moist environments (Round, 1984; Büdel et al., 1994). Small epiphytic liverworts (e.g., Lejeuneaceae) are common on large foliose cyanolichens, especially in wet tropical forests. When growing on epiphytic lichens, these organisms can be called hyperepiphytes.

While most free-living algae and cyanobacteria are clearly not acceptable symbiotic partners for lichen-forming fungi, some lichen mycobionts which are initially unable to establish associations with suitable photobionts, may preliminarily exploit free-living algae or cyanobacteria, until more suitable photobionts are encountered (Ott, 1987; Gassmann and Ott, 2000). Recently, Etges and Ott (2001) demonstrated that axenically grown and transplanted lichen mycobionts could survive for over a year in their natural habitat.

\section{STRUCTURAL - FUNCTIONAL ORGANISATION OF CYANOLICHENS}

Rambold and Triebel (1992) suggested that in lichens, symbiosis should be understood in a broad sense, including the phenomena of mutualism, commensalism, and possibly parasitism. They described lichens as stable two-, three- or sometimes four-biont systems. The multibiont associations include the cephalodiate cyanolichens, but also systems that have bi- or tripartite lichens as primary parts and lichenicolous fungi or lichens as accessory parts (Hawksworth, 1988; Rambold and Triebel, 1992). In many lichens the relationships between the bionts are not static, but can change depending on environmental conditions and the ontogenetic phases of the bionts or the symbiotic consortium (Richardson, 1999).

All lichen-forming fungi exploit photobionts for their own benefit. However, they also depend on the efficiency of the photobionts in capturing, transforming and translocating solar energy. Many external factors, like the intensity of ambient illumination, water availability, temperature, and the ionic environment can influence net photosynthesis (see next chapter). In this context the lichen thallus can be seen to provide as a relatively stable environment for lichen photobionts. Usually the lichen-forming fungus mediates almost all interactions between the photobionts and the outside world and, by doing so, cushions the impact of environmental extremes. For example, some lichen photobionts are relatively sensitive to strong light. Inside lichen thalli these organisms can exist in numbers that would be impossible without the protection of the fungus. This may significantly increase their ability to multiply (Rikkinen, 1995).

While lichenized algae and cyanobacteria may often show lower net productivities per unit area and lower specific growth rates than their free-living counterparts, the stature of lichen thalli often projects the photobionts high above their free-living counterparts. This may represent a significant advantage in the competition for limiting resources, such as light, water and mineral dust (Raven, 1993). A three-dimensional thallus also lifts the photobionts above the surface boundary layer of the substrate. Many foliose and fruticose lichens have high surface-to-volume ratios and low heat capacities. Thus, they provide ideal condensation points for atmospheric humidity (Rikkinen, 1995, 1997). 


\subsection{Types of Cyanolichens}

On the basis of symbiont composition most cyanolichens can be conveniently divided into two main groups: bipartite and tripartite cyanolichens. According to their overall appearance they have traditionally been divided into three main categories: crustose, foliose and fruticose lichens. Both divisions are artificial and convergent forms have repeatedly evolved in different systematic groups. However, the categories are quite useful and widely used for descriptive purposes.

\subsubsection{Bipartite and Tripartite Cyanolichens}

Bipartite lichens are stable symbioses between one type of lichen-forming fungus and one type of cyanobacterial photobiont (Fig. 3A). In most bipartite cyanolichens, the cyanobionts form a more or less continuous photobiont layer below the upper cortex. Tripartite lichens contain both green algal and cyanobacterial symbionts in addition to the lichen-forming fungus (Figs 3B and 3C). Tripartite lichens include species which house symbiotic cyanobacteria in external or internal cephalodia, species that have both types of photobionts within the same main thallus but in separate sublayers, and the species which form pairs of disparate morphs originating form the interaction of the same fungus with the two contrasting types of photobionts. In most tripartite lichens the green algal photobiont occupies much of the thallus and produces most of the photosynthate. However, there are also some species in which cyanobacteria dominate and the phycobionts are limited to restricted parts of the thallus (James and Henssen, 1976; Henssen et al., 1987).

Symbiotic cyanobacteria can provide both photosynthate and fixed nitrogen to their fungal partners and the relative importance of these functions varies between bi- and tripartite symbioses. The cyanobionts of tripartite lichens tend to show higher heterocyst frequencies and higher rates of nitrogen fixation than those of bipartite species (Rai et al., 2000; see also chapter 6).

Cephalodiate Lichens and Photosymbiodemes. Tripartite lichens with cephalodia are by far the best known examples of multibiont systems among lichens (Fig. 3B). Cephalodia are delimited structures containing cyanobacteria in an otherwise green algal lichen thallus. External or internal cephalodia are known from over 500 lichen species, and similar structures have clearly evolved independently in repeated instances in lichens representing different systematic groups (Table 1). The cephalodial anatomy of many tripartite species of Lobaria, Nephroma, Peltigera, and Stereocaulon have been studied in detail (Forssell, 1883; Lamb, 1951, 1968, 1976; Jordan, 1970, 1972; Jordan and Rickson, 1971; James and Henssen, 1976; Stocker-Wörgötter and Türk, 1994). In some tripartite lichens the cephalodia are located deep inside the thallus or on the lower surface. This supports a primary role of the cyanobiont in nitrogen fixation over that in photosynthesis.

The mycobionts of some cephalodiate lichens can produce different morphotypes in symbiosis with compatible green algal and cyanobacterial photobionts. Such morphotypes may either combine into a compound thallus or live separate lives. Chimeroid lichens with green algae and cyanobacteria as primary photobionts in different parts of the same thallus are called photosymbiodemes (Fig. 3C). The corresponding free-living morphotypes have been called 
chlorosymbiodemes or chlorotypes and cyanosymbiodemes or cyanotypes, respectively. Photosymbiodeme producing species are known from several lecanoralean genera (Lobaria, Nephroma, Peltigera, Pseudocyphellaria, and Sticta). As a whole, however, photosymbiodemes are quite rare and most cephalodiate lichens do not seem to produce chimeroid thalli.
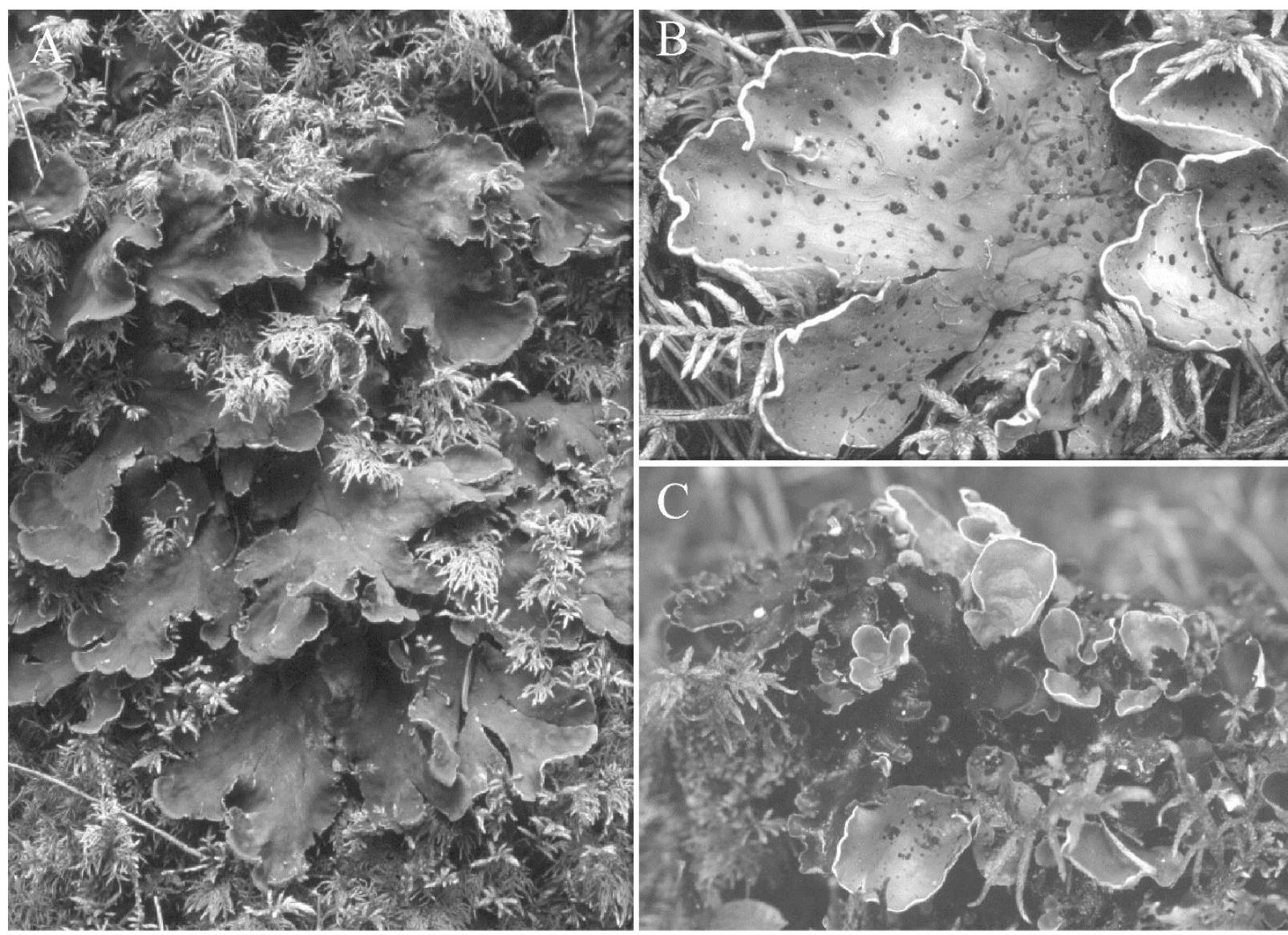

Figure 3. Main types of cyanolichens: (A) bipartite Peltigera neopolydactyla, (B) tripartite Peltigera aphthosa, and (C) photosymbiodeme of Peltigera aphthosa.

The biont composition and taxonomy of photosymbiodemes have evoked considerable interest from lichenologists (James and Henssen, 1976; Brodo and Richardson, 1979; Tønsberg and Holtan-Hartwig, 1983; Vitikainen, 1994; Goffinet and Bayer, 1997; Goward and Goffinet, 1998; Jørgensen, 1994, 1997, 1998; Paulsrud et al., 1998, 2000; Socker-Wörgötter, 2001a,b; Tønsberg and Goward, 2001). Furthermore, photosymbiodemes have offered unique opportunities for the study of differences in the physiological performances of symbiotic green algae and cyanobacteria under similar conditions of growth, habitat, history and fungal association (Demmig-Adams et al., 1990; Green et al., 1993; Schelensog et al., 2000; Stocker-Wörgötter, 2001a, b). 


\subsubsection{Growth Forms}

Most cyanolichens fit well into one of the three main growth form categories: crustose, foliose and fruticose. Prominent exceptions include the species of Dictyonema, which do not produce thalli, but house their cyanobionts within thin, papery basidiomata. Also some mycophycobiosis-like cyanolichens are difficult to categorize. All growth form categories include both bipartite and tripartite symbioses. Many cyanolichens appear gelatinous when wet. Gelatinous species are found in all three growth form categories. Gelatinous cyanolichens tend to produce nonstratified, homoiomerous thalli in which the mycobiont hyphae run directly within the extracellular matrix of cyanobionts and there is no distinct photobiont layer. These lichens are known for their ability to absorb large quantities of water due to the abundant production of cyanobacterial mucilage.

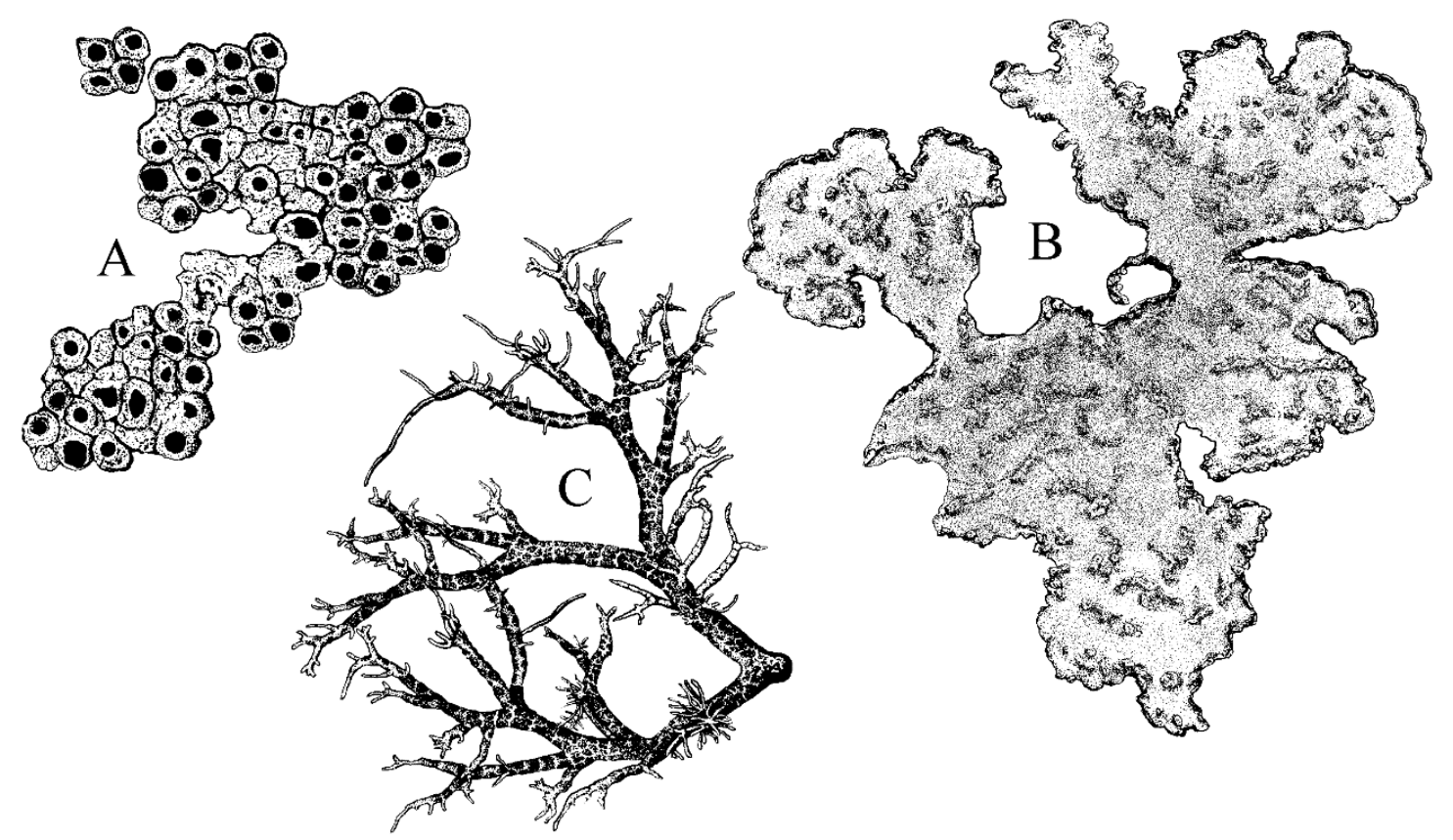

Figure 4. Growth forms of cyanolichens: (A) crustose Psorotichia diffracta, (B) foliose Pseudocephallaria anomala (C) fruticose Ephebe lanata.

Crustose Cyanolichens. Crustose lichens produce relatively undifferentiated, crust-like thalli which often grow tightly attached to their substrate. The crustose growth form is less common among cyanolichens than among green algal lichens. However, many species of Lichinales produce crustose thalli and many lichenicolous and cyanotrophic species are indeterminate or crustose (Table 1). The crustose thallus may be granular and effuse, like in Moelleropsis, or areolate, like in Euopsis and Lemmopsis. In areolate lichens the crustose thallus is broken up into numerous, scattered or aggregated entities. In some cases the areolae may initially develop on the surface of a fungal prothallus. Most crustose cyanolichens are episubstratic, i.e., they grow on the surface of their substrate. Some taxa, like species of Pyrenocollema, are endosubstratic, i.e., they mostly grow inside the substratum. Endolithic species grow in minute cracks and cavities or between mineral crystals of a rock. 
Foliose Cyanolichens. Most cyanolichens produce foliose, distinctly lobate thalli (Table 1). These taxa are typically dorsiversal, flattened and their growth is predominately horizontal. This gives the lichens a more or less leafy appearance. The foliose thallus may only consist of a single lobe, which is then usually rounded, or the outwardgrowing thallus edge is divided into many lobes. Squamulose cyanolichens, like many species of Heppia and Psoroma, are somewhat intermediate between crustose and foliose forms. Their thalli consist of small, dorsiventral lobules or squamules which develop individually and may remain distinct from each other. Other intermediate forms include some species of Pannaria (thallus partly crustose and partly lobulate) and numerous species of Lichinales (lobulate thallus margins but subfruticose central parts).

Both the form and size of thallus lobes are often quite characteristic for specific cyanolichen taxa. Some foliose cyanolichens, like Parmeliella, produce relatively small thalli with narrow and small thallus lobes. Others, like species of Lobaria and Peltigera, may produce very large, wide-lobed thalli. The thalli of most foliose cyanolichens are heteromerous and have a well developed cortex on the upper surface. Below the cortex there is a more or less uniform cyanobiont layer followed by a medulla of loosely intertwined hyphae. Some foliose cyanolichens, like Collema, produce gelatinous, homoiomerous thalli without a specialised cortex, medulla or photobiont layer. Other gelatinous forms, like Leptogium, have a thin cortex on the outer surface.

The lower surface of foliose cyanolichens may either be corticated, like in Nephroma, or ecorticate, like in Peltigera. Most species attach to their substrate with rhizines. In some taxa, like in species of Coccocarpia, entangled rhizines may project far beyond the thallus margins and form an extensive hypothallus. The thalli of some single-lobed and squamulose cyanolichens, like species of Peltula and Peltularia, attach to their substrate with single, usually central holdfasts and are thus more or less peltate.

Fruticose Cyanolichens. Fruticose, shrubby growth forms are relatively rare among cyanolichens (Table 1). Some fruticose taxa, like Lichina and the dendriscocauloid cyanotypes of Sticta, produce more or less upright, shrubby thalli that are attached to their substrate by a relatively narrow base. Others, like species of Ephebe and Lichinodium, produce mats or rosettes of minute, decumbent to semi-erect branches. The fruticose thallus may be corticated or ecorticate, and in heteromerous forms there is a distinct photobiont layer and a central medulla in the thallus lobes.

During their development, species of Pilophorus and Stereocaulon tend to first produce a basal crust and then larger upright pseudopodetia. The pseudopodetia of Stereocaulon are solid, ecorticate and support innumerable corticated appendages called phyllocladia. Also wart-like cephalodia may occur in large numbers. The threedimensional, often richly branched pseudopodetia are firmly attached to their substratum by special attachment hyphae.

\subsection{The Lichen Thallus}

The symbiotic lichen body is called the thallus. Most structures in lichen thalli develop through processes induced in the lichen mycobiont by the photobiont. General features of thallus morphology and anatomy have been covered in many reviews (Jahns, 1973; Jahns, 1988; Rikkinen, 1995; Büdel and Scheidegger, 1996) and more detailed accounts can be found in monographs on different taxonomic groups. General descriptions of thallus morphology are also 
found in many recent lichen floras (Wirth, 1980, 1995; Clauzade and Roux, 1986; Purvis et al., 1992; Goward et al., 1994; Goward, 1999; McCune and Geiser, 1997; Kantvilas and Jarman, 1999) and textbooks (Nash, 1996; Baron, 1999; Awasthi, 2000; Purvis, 2000). A brief account is given here.

\subsubsection{Thallus Anatomy}

Although lichens produce a limited variety of cell types, they show a remarkable degree of differentiation and structural complexity. This is achieved by a highly flexible developmental process and multifunctional structures (Ott, 1993). The fungal hyphae often differentiate into hygrophilic, pseudoparenchymatous zones or more loosely interwoven zones composed of aerial hyphae with water-repellent surfaces. The pseudoparenchymatous zone can form a peripheral cortex which covers or encloses a more loosely interwoven medulla. With some variations, this basic organization is seen in most lichens with a heteromerous thallus structure (Honegger, 1991; Letrouit-Galinou and Astra, 1994).

All lichenized fungi produce septate hyphae. In loosely organized lichen tissues, the hyphae are usually more or less cylindrical in form and have relatively thin walls. In modified tissues their shape may change; hyphal tips can grow, differentiate and the mutual pressure from adjoining cells influences their shape. The cell wall composition of lichen mycobionts is similar to that of other filamentous ascomycetes; the walls consist mainly of polysaccharides, with smaller amounts of proteins and lipids. While glucose has been found to be the most abundant polysaccharide monomer, mannose, galactose and glucosamine are also present. Chitin forms a dense meshwork on the inner cell wall surface of mycobiont hyphae. The ultrastructure of the hyphal walls may depend on the position and function of the hyphae; the thinnest hyphal walls, only 150-400 nm thick, are usually found in the photobiont layer. Medullary hyphae tend to be covered by layers of extracellular material. Extracellular sheaths may increase the surface area of the hyphae, hold photobiont cells in contact with the hyphae and act as channelling device for water transport and solute translocation. Within the cortex all spaces between neighbouring hyphae are often filled with amorphous substances secreted by the fungal cell walls (Jahns, 1988; Peveling, 1988; Honegger, 1991, 1997).

The thallus lobe of a typical cyanolichen consists of lengthened axial hyphae with unlimited growth which produce lateral branches with finite growth. The axial hyphae ensure the continuous elongation of the thallus lobe, while the lateral branches ensure the thickening of the thallus. The highest rates of cell division and metabolic activity of lichen bionts usually occur within a relatively narrow marginal or apical growth zone. In older parts of the thallus, growth may be limited to the slow turnover of cells in the photobiont layer and cortex and a slight volume increase of the medulla. Also the gradual accumulation of extracellular material is quite characteristic.

The morphology and anatomy of many lichens is strongly influenced by the environment. For example, the overall shape of the thallus, thickness of different thallus layers and the development of pigments and refractive structures all influence the quality of light that reaches the photobiont cells. Many lichens, particularly gelatinous ones, can exhibit major changes in dimensions during their normal wetting and drying cycles. These phenomena are generally related to the colloidal mechanism of water absorption and storage within lichen thalli (Rikkinen, 1995, 1997). 
The Protective Cortex. A solid cortex protects lichen cyanobiont against physical abrasion, pathogens, excessive light and rapid desiccation. However, the cortex must be translucent enough to allow sufficient amounts of light to reach the photobiont cells. A dense cortex may also seriously hinder gas exchange and thus many structurally complex cyanolichens have special respiratory openings in their cortex. Species of Sticta have cyphellae, and species of Pseudocyphellaria pseudocyphellae, in the lower cortex. In some cyanolichens thallus aeration takes place through less specialized, multifunctional openings, such as soralia. Others, like species of Peltigera, lack the lower cortex altogether.

Cortex structure can vary considerably between closely related lichen species and even between different parts of a single thallus. Many examples of this can be seen in Peltigera (Vitikainen, 1994; Dietz et al., 2000). In some cyanolichens the cortex surface is formed by dead hyphae. These can give rise to pruina or thick epinecral layers (Büdel, 1990; Büdel and Lange, 1994). Other lichens accumulate thick crusts of calcium oxalate crystals on their surface. The spectral characteristics of most lichens change quite dramatically depending on thallus water content. Minute air-cavities within the cortex scatter light effectively. When the cortex is moistened, water is absorbed into the cell walls and the interhyphal matrix. As a result, the cortical tissues swell and the number of vertical cell walls and the density of the extracellular matrix per unit area is reduced. Also cortical pigments are spread over a wider area. All these phenomena act to increase light availability within the photobiont layer (Rikkinen, 1995).

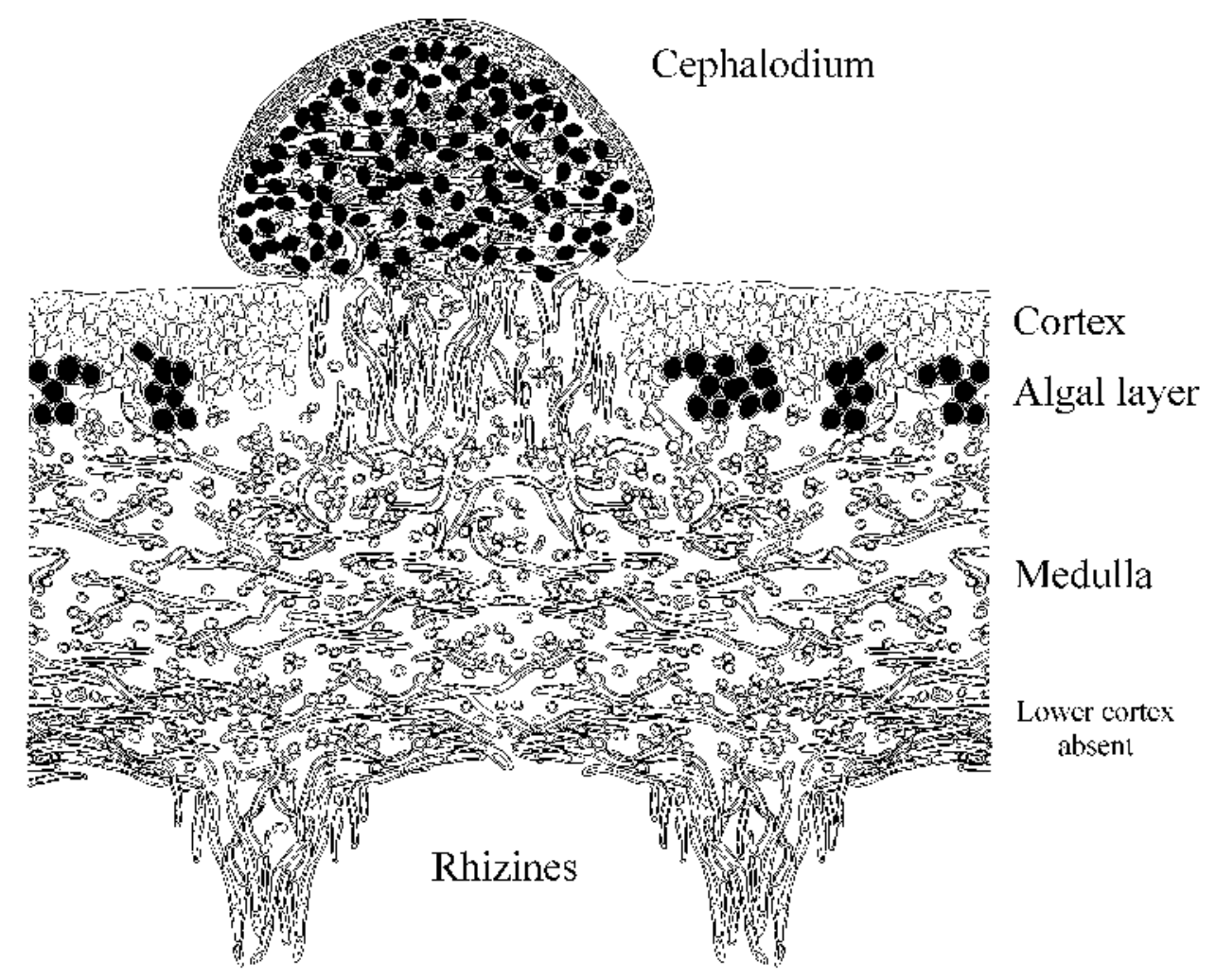

Figure 5. Diagrammatic cross-section through the thallus of the cephalodiate lichen Peltigera species. 
Photobiont Layer and Medulla. In heteromerous cyanolichens the cyanobiont cells are usually positioned into a relatively uniform layer in the uppermost part of the medulla. The horizontal distribution of the photobiont cells with respect to the thallus surface can show considerable variation. The exchange of metabolites requires a very close connection between lichen symbionts and several types of mycobiont-photobiont contacts occur in cyanolichens. These include wall-to-wall appositions, intracellular haustoria in some species, and intragelatinous protrusions in many heteromerous taxa. In many cyanolichens, thin-walled mycobiont hyphae penetrate the gelatinous sheaths of the cyanobionts, but there is no direct contact between the cell walls of the symbionts. Intracellular haustoria are only found in 'primitive' interactions such as those between species of Dictyonema and Scytonema (Oberwinkler, 1984). In addition to some chytrids and cyanophilous ascomycetes these lichen-forming basidiomycetes are among the few eukaryotic organisms that actually penetrate into bacterial cells in search for nutrients.

Most green algal lichens with trebouxioid phycobionts produce intraparietal haustoria in which the waterrepellent cell-wall surface layers of mycobiont hyphae spread to cover the algal cells. This type of haustorial complex fulfils several functions. It is the site of carbohydrate mobilisation from the photobiont to the fungus. Water, minerals, and fungal metabolites are translocated in the apoplastic continuum below the mycobiont derived surface layer of algal cells. Finally, the haustorial complex may help in the positioning of the photobiont cells within the photobiont layer (Honegger, 1997). The photobionts of most lichens are under some type of limiting control by the lichen-forming fungus. The mycobiont may control the photobiont population by draining photosynthate or by killing of surplus cells. Usually the excessive build-up of photobionts is avoided by arrests in the normal cell cycles of the photobionts (Hill, 1989, 1993). Some of these phenomena may be related to the kinetics of light-energy limited growth (Rikkinen, 1995). Water transport within heteromerous lichens is largely a function of the mycobiont. The water-repellent surfaces of medullary hyphae help to maintain a gaseous environment within the medulla. Thus, the medulla of a tripartite Peltigera species, for example, remains air-filled even at water saturation (Honegger and Hugelshofer, 2000). The outer wall layers of thick medullary hyphae may hold large amounts of weakly perturbed water. This, together with the general lack of liquid water within the interhyphal spaces of fully hydrated lichens, indicates that apoplastic water transport takes place under the hydrophobic surface layers of medullary hyphae. However, the hyphae of some cyanolichens, like Nephroma resupinatum, have relatively thin walls and therefore, may not be very efficient in apoplastic water transport (Scheidegger, 1994).

Some lichens produce specialized strands of intertwined and conglutinated hyphae which can conduct water from the thallus surface to the photobiont cells. For example, the corticated cephalodia on the upper surface of tripartite Peltigera thalli may be connected to the ecorticate lower surface by strands of hydrophilic hyphae (Honegger and Hugelshofer, 2000). Water is absorbed and translocated by capillary forces along these tomental strands. As a result, the cephalodial cyanobionts have effective access to substrate moisture. The green algal photobionts, on the other hand, depend on slower apoplastic translocation of water (Honegger and Hugelshofer, 2000). While green algal photobionts can partly rehydrate from humid air, cyanobacteria tend to require liquid water for effective rehydration (Lange et al., 1986, 1989; Büdel and Lange, 1991; Scheidegger, 1994). For example, in a recent study of green algal and cyanobacterial Pseudocyphellaria species, photosynthesis in the green algal thalli was 
activated at ca $20 \%$ water content, while the cyanobacterial thalli required a minimum water content of ca $50 \%$ DW (Schlensog et al., 2000).

Lichen Propagules. The diversity of lichen-forming organisms makes it difficult to embrace the full range of structures and mechanisms that are involved in the reproduction of lichens. Each symbiotic partner may produce its own diaspores, and often one symbiont produces several types of propagules. For example, many lichen-forming ascomycete produce sexual ascospores as well as asexual conidia. Both types of propagules can be produced in enormous numbers. Motile hormogonia, on the otherhand, help nostocalean cyanobacteria to establish symbioses with many types of organisms, including lichen-forming fungi (Adams 2000; Rai et al., 2000).

In addition to producing propagules of individual symbionts, many lichens facilitate the reproduction and simultaneous dispersal of the whole symbiotic consortium. In some lichens this is achieved simply via thallus fragmentation. Other species produce specialized symbiotic propagules, such as isidia or soredia. Isidia are small corticated outgrowths of the lichen thallus that usually break off in one piece. Soredia are minute ecorticate masses of mycobiont hyphae containing only a few photobiont cells. They are usually produced in special structures called soralia. Isidia and soredia are formed usually in specific parts of the lichen thallus. Some Lempholemma species produce hormocystangia at the margins or tips of their thallus lobes. These swollen structures are filled with short lichenized Nostoc filaments, which are liberated with the decay of the structures (Henssen, 1963).

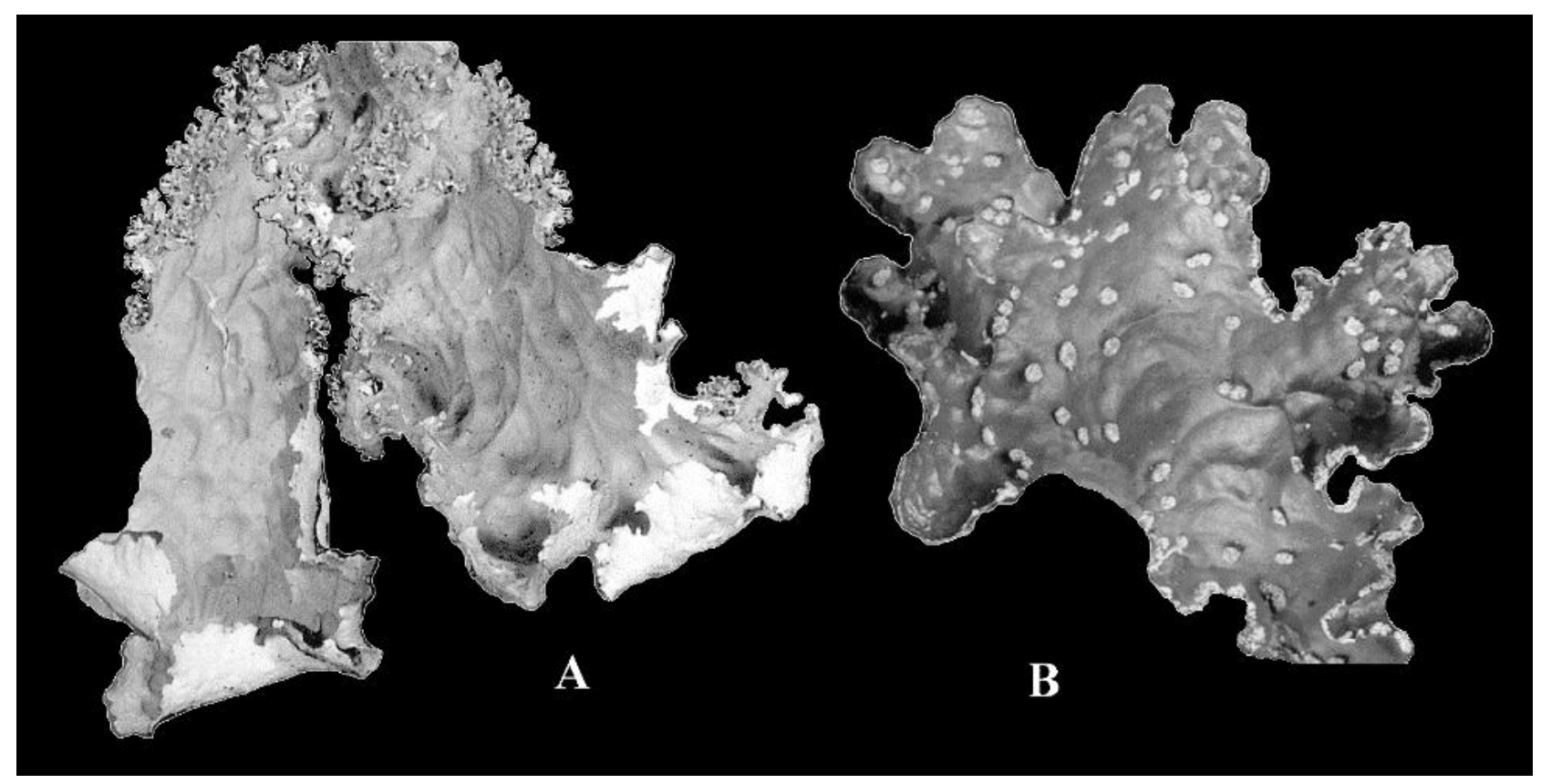

Figure 6. Symbiotic propagules of foliose cyanolichens: (A) dorsiventral, marginal phyllidia in Lobaria oregana, (B) laminal and marginal soralia in Pseudocyphellaria erocata. 
The mycobionts of some lichens are rarely fertile and such species obviously depend on vegetative reproduction. However, as most lichen species are not known to produce specialized symbiotic diaspores, they seem to re-establish their symbiosis at each reproductive cycle. The possible importance of symbiotic dispersal in the ecology of many cephalodiate cyanolichens remains somewhat an enigma, as most of these lichens do not have symbiotic propagules. However, some Psoroma species do produce sorediate, isidiate or phyllidiate cephalodia (Jørgensen and Wedin, 1998).

\subsubsection{Thallus Morphogenesis}

Soon after the association between a compatible fungus and photobiont is established, the symbiosis starts to express morphological and chemical characteristics of a 'lichen' e.g., internal stratification and the accumulation of specific secondary metabolites. As the photobionts provide energy for the whole symbiosis, the growth and subsequent differentiation of the predominately fungal thallus is probably stimulated by initial growth of the photobiont. Indeed resynthesis experiments have shown that under suitable conditions a compatible photobiont triggers the expression of the symbiotic fungal phenotype, although the mechanism remains unknown (Ahmadjian, 1993; Galun and PelegZuriel, 2000).

The Symbiotic Phenotype. Aposymbiotically grown lichen mycobionts tend to produce a different hyphal arrangement than their lichenized counterparts. Apically growing and branching hyphae often form exploratory indefinite mycelia, quite similar to many non-symbiotic filamentous fungi. The colonies often have cartilaginous, conglutinate central parts with aerial hyphae at the periphery. Whereas lichenized mycobionts exhibit polarised growth, with distinct growth zones being the rule, aposymbiotic mycobionts tend to grow in a centrifugal manner (Honegger, 1991). In addition, the morphology of lichen photobionts is often greatly modified by lichenization. For example, the Nostoc cyanobionts may appear to reside as single cells, in honeycomb like chambers formed by the fungal partner (Kardish et al., 1989; Scheidegger, 1994). Changes in the arrangement and amount of thylakoid membranes are also observed (Bergman and Hällblom, 1982). Many cyanobacteria undergo major changes in cell size and shape during the lichenization. Sometimes lichenization leads to a reduction in cell size but in most cases there is a significant increase in cell size, especially in older parts of the thallus. Presumably the drain of metabolites to the mycobiont affects the balance between reproduction and enlargement.

Until recently cyanolichens could not be resynthesized as successfully as green algal lichens (Ahmadjian, 1989, 1993). However, methods are now becoming available to perform resynthesis experiments with many types of cyanolichens, including photosymbiodemes. For more information the reader is referred to recent reviews by StockerWörgötter (2001a, b). Future resynthesis experiments will undoubtedly help to elucidate many ontogenic principles in the development of cyanolichen thalli. One may also expect that new information of underlying molecular processes, such as DNA-methylations, will soon become available (Armaleo and Miao, 1998).

Resynthesis studies with lichens have generally shown that the genetic control of thallus formation is closely linked to such ecological factors as drying-wetting cycles and prevailing light intensities. For example, StockerWörgötter and Türk (1994) found that relatively dry growth conditions were important for the formation of 
cephalodia in resynthesized Peltigera thalli. As long as the cultures were kept wet, Nostoc filaments escaped from loose precephalodial structures. During drier periods the cyanobacteria were effectively integrated into a fungal network and finally surrounded by a cortex. Similar phenomena were also reported by Yoshimura et al. (1994), who could not induce the formation of normal cephalodia in wet $P$. aphthosa cultures.

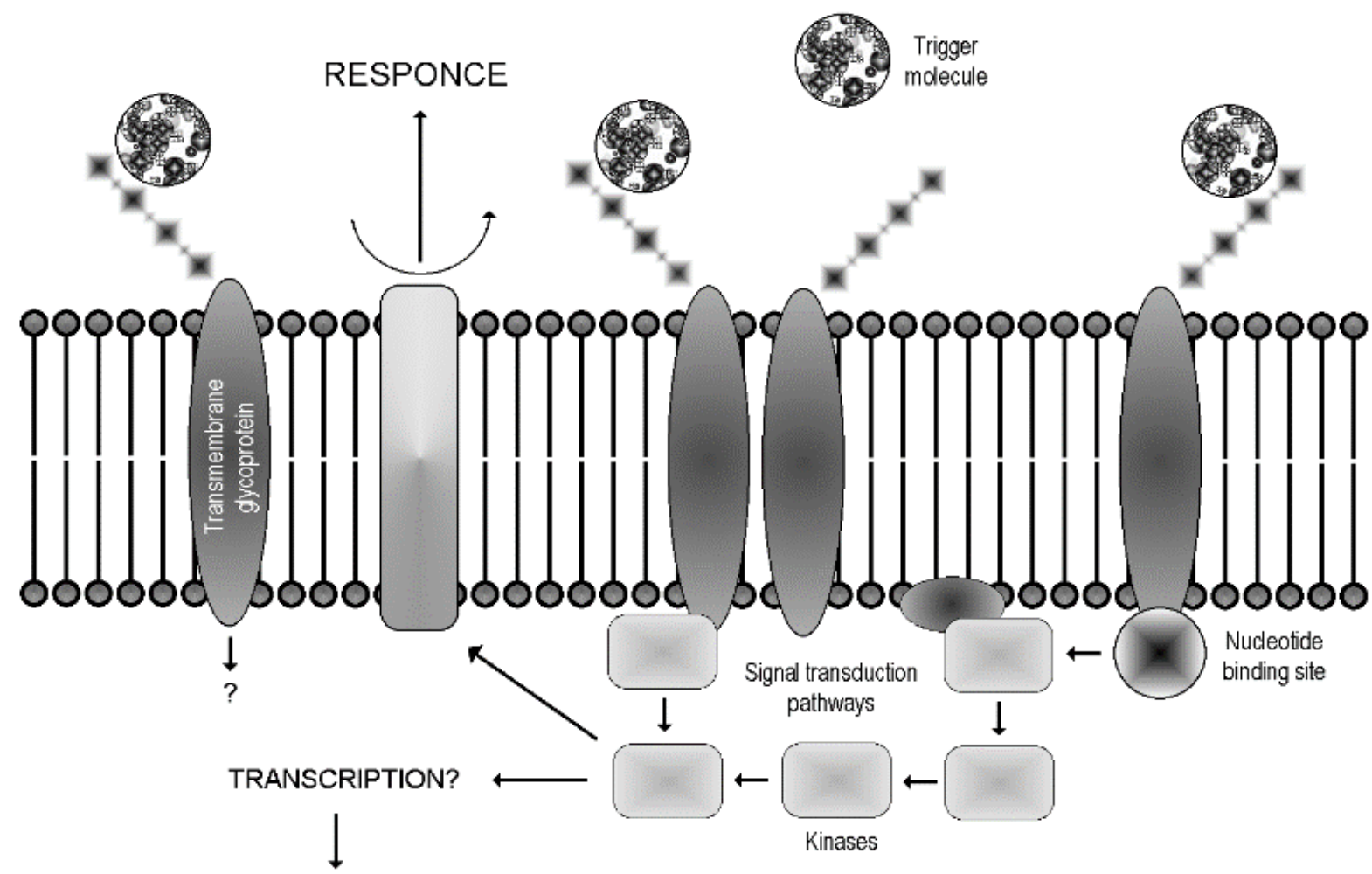

RESPONCE

1. Trigger molecules. 2. Signal recognition through transmembrane proteins. 3 . The inner membrane part of the protein may function as a kinase, transmitting signals to cellular mechanisms resulting in interbiontic response. 4 . Interbiontic response is transmitted out of the cell by membrane associated proteins. 5. The interbiontic response in the cell is transmitted through kinases and other factors.

Figure 7. A model for signalling between symbionts in lichen. Two types of signalling elicitors are known: general elicitors without major differences in sensitivity among responding organisms, and specific elicitors that function in specific ways. General elicitors are usually substances associated with primary metabolism, and include glucans, chitin oligomers, glycopeptides, cell wall fragments, and many phenolics. Specific elicitors may include proteins, peptides, syrincolides, and phenolic compounds (Rikkinen and Pappinen, unpublished results).

Recognition and Signalling. The potential partners for a lichen symbiosis are germinating fungal propagules and freeliving or lichenized photobiont cells. Signalling between compatible symbionts must be mediated by chemicals produced by a symbiont (Fig. 7). Yoshimura and Yamamoto (1991) found that during the resynthesis of Peltigera praetextata the transformation of Nostoc colonies into the symbiotic state occurred even without a direct contact 
with the mycobiont. Thus, some sort of a diffusible soluble substance from the mycobiont controlled the transformation of Nostoc. Such phenomena are also known from other types of cyanobacterial symbioses (Adams, 2000). Cyanobacteria and lichen-forming fungi produce hundreds of unique secondary metabolites and novel compounds are continuously being described. Among fungal metabolites the aromatic polyketides are especially well represented. The structure and biosynthesis of these lichen compounds have been studied extensively, but their possible roles in symbiont recognition are presently unknown (Rikkinen, 1995; Huneck and Yoshimura, 1996).

Lectins attach to tissue components, notably glycoproteins, with a high degree of specificity. In fern and bryophyte symbioses, for example, the host plants produce lectins which recognize sugar residues on the cell surfaces of symbiotic Nostocs (Bergman et al., 1993). Kardish et al. (1990) studied the binding of lectin isolated from the fungal component of Nephroma laevigatum to Nostoc cells from different origins and concluded that the protein was involved in the control and regulatory processes of symbiont balance in the lichen thallus. Lectins have also been isolated from mycobiont hyphae of some Peltigera species (Lehr et al., 1995; Rai et al., 2000). In P. aphthosa a lectin recognizes compatible Nostoc cells at the initiation of cephalodium formation and this process is highly specific (Lehr et al., 2000). The specificity for cyanobiont was confirmed in a recent inoculation study attempting to introduce foreign Nostoc strains into the cephalodia of P. aphthosa (Paulsrud et al., 2001).

\subsection{Cyanolichens as Symbiotic Processes}

Taxonomic and morphological definitions do not do full justice to the biological essence of lichens. While the thalli of some species are reasonably well delimited, they never function as individuals in the conventional sense of the word. This is because phenotypic and genetic attributes do not coincide. In many lichens even a mechanistic delimitation of a single thallus is quite impossible. Many lichens rely almost exclusively on vegetative reproduction and often this leads to innumerable genetically identical thalli. This may partly explain why the morphology and ecology of many lichen species is remarkably similar throughout their range. On the other hand, some lichens start their development with the fusion of several symbiotic propagules. The genetic structure of such thalli may be quite complex.

\subsubsection{Some Implications of Biont Specificity}

Many studies have shown that most lichen-forming fungi are highly selective in choosing photobionts. This applies to both green algal photobionts and cyanobacterial photobionts. It thus seems that only a narrow spectrum of closely related photobiont taxa induce the transformation of a specific fungus into the symbiotic phenotype. However, the mode of cyanobiont acquisition may have a bearing on the cyanobiont diversity in lichen thalli and other cyanobacterial symbioses (Rai et al., 2000).

In all bipartite cyanolichens studied so far, only one cyanobiont strain has been detected from each thallus. Also most tripartite lichens have contained the same Nostoc strain in all cephalodia of individual thalli (Paulsrud, 2001). The main exception is $P$. venosa which can often house different cyanobionts in different cephalodia (Paulsrud et al., 2000). Ott (1988) reported that even cyonobionts resembling Scytonema can occur together with Nostoc both in the prothallus and later developmental phases of $P$. venosa. Some Nephroma thalli also seem to occasionally house 
different types of cyanobacteria in different cephalodia or possibly even in the same cephalodium (Jordan and Rickson, 1971). Some species of Stereocaulon are believed to evolve cephalodia with representatives of several different cyanobiont genera (Lamb, 1951). These diversity patterns have not yet been confirmed with modern methods.

\subsubsection{Fungal Compatibility}

Molecular studies have clearly indicated that the same fungus is responsible for both types of photobiont associations in tripartite Peltigera species. This information has been gained from hybridisation studies of restriction digests of total DNA and restriction site comparisons of PCR products (Armaleo and Clerc, 1991), or from comparative studies of $5.8 \mathrm{~S}$ and ITS sequences (Goffinet and Bayer, 1997). It is still possible that more than one genetically discrete individual or genet could be involved. Subtle variations in the morphology and secondary chemistry of many Peltigera species could reflect different combinations of genets within specific thalli or groups of thalli. Some of them might even represent complex, three-dimensional puzzles involving a large number of genets.

Many features of sexual and vegetative compatibility in lichen mycobionts are quite identical to those of nonlichenized ascomycetes. Thus, there is no reason to believe that the genetic systems which control these phenomena would be any more dissimilar. For example, anastomoses between mycobiont hyphae are common in some lichens. In the Peltigeraceae they are often accompanied by bi- or multinucleate hyphae. In such cases, the genetic integrities of mycobiont genets could be controlled by series of bi- or multi-allelic genes at vegetative incompatibility (het) loci, typical of many non-lichenized ascomycetes. In addition, mating-type alleles could function as incompatibility genes, along with several other loci (Glass and Kuldau, 1992; Leslie, 1993; Coppins et al., 1997). Unfortunately, many aspects of sexual and vegetative compatibility in lichen mycobionts have not yet been studied in detail (Larson and Carey, 1986; Culberson et al., 1988; Goffinet and Hastings, 1995; Murthach et al., 2000). Further studies on these topics are needed in to get new insights into the basic biology of lichen symbioses.

It is easy to imagine how lichens could benefits from maintaining a certain level of fungal heterogeneity within their thalli. In addition to different aspects of sexual reproduction, the mycobionts could gain through an increased resistance against viruses and other pathogens. The presence of several vegetative compatibility types within each thallus could restrict the spread of intracellular pathogenes as hyphal fusions would not develop between different compatibility groups. From this perspective, one might even hypothesise that a certain level of vc-heterogeneity is not only possible, but required for the success of slow-growing and long-lived lichen thalli.

\subsubsection{Cyanolichen Guilds}

Different thalli of individual cyanolichen species can often contain different strains of symbiotic cyanobacteria. Futhermore, different cyanolichen species can often share identical cyanobiont strains (Paulsrud et al., 1998, 2000). Often several such lichen species co-occur in specific habitats and form characteristic communities or 'guilds'. The cyanobionts of all lichens within each guild are closely related, but not the lichen-forming fungi. Some guilds include mycobionts from many different genera or even different families. On the other hand, some closely related 
mycobionts associate with different types of cyanobionts and thus belong to different guilds. This implies that many cyanolichens not only share similar enviromental requirements, but also depend on a common pool of cyanobacterial symbionts. This common phenomenon influences the structure of lichen communities on all levels of community organization (Rikkinen, Oksanen and Lohtander, unpublished results).

For example, bipartite Nephroma species and similar epiphytic cyanolichens form a characteristic group among the epiphytes of humid boreal and temperate forests. Many of these lichens prefer old-growth forests and they have been used as biological indicators of forest antiquity. These species are usually positioned relatively low in the vertical zonation of epiphytes (McCune, 1993). They are thus well buffered from extremes of temperature, exposure to wind, and desiccation, but must survive under illumination conditions drastically different from those in more open habitats (Rikkinen, 1995). Studies of cyanobiont diversity have recently indicated that many old-growth associated cyanolichens depend on a specific group of symbiotic Nostoc strains that are not found in other types of cyanolichens (Fig. 8). These lichens exploit a common pool of cyanobacteria and form a horizontally linked system, the 'Nephroma guild'. Conversely, many predominately terrestrial cyanolichens in the same forests share a different group of closely related Nostoc strains, thus forming the 'Peltigera guild'. These two cyanolichen guilds meet on the basal trunks of broad-leaf trees and probably represent a fair proportion of similar guilds in boreal forests (Rikkinen, Oksanen and Lohtander, unpublished results).

Considering the dispersal of cyanolichen species it would seem unnecessary for all lichen mycobionts to spend resources in producing symbiotic propagules, when other guild members will effectively disperse the same cyanobiont. Thus, the dispersal ecology of many lichen guilds may centre around 'core species', which produce massive amounts of symbiotic diaspores. 'Fringe species', in turn, produce only fungal propagules and may largely depend on the core species in the dispersal of appropriate cyanobionts. In their natural habitat both types of cyanolichens can exist side by side without much competition for space. The competition between guild members is reduced by slightly different substrate preferences and thallus morphologies. Furthermore, the core species may actually benefit from the fringe species, as their extra cyanobionts are being deposited into neighbouring guild members rather than being completely lost. Some of these symbionts can be potentially reclaimed as, without the ability to produce symbiotic propagules, the fringe species cannot transfer the cyanobionts into new habitats. This phenomenon may explain why the existence of competition is often difficult to demonstrate in lichen communities. Further studies on guild structure are essential for a better understanding of lichen ecology and for the development of viable conservation strategies for maintaining high cyanolichen diversity in remnant old-growth forests. Special emphasis should be given to the design of experimental approaches for the study of lichens as horizontally linked symbiotic processes (Rikkinen, 1995; Rikkinen, Oksanen and Lohtander, unpublished results).

\subsubsection{Continuum Between Bipartite and Cephalodiate Cyanolichens}

Cephalodiate species of the Peltigerinae have often been interpreted as advanced forms of symbiosis. However, some recent findings have indicated that the cephalodiate taxa should not automatically be regarded as more 'advanced' than bipartite species. On the contrary, many bipartite lichens may have evolved from tripartite ancestors. 

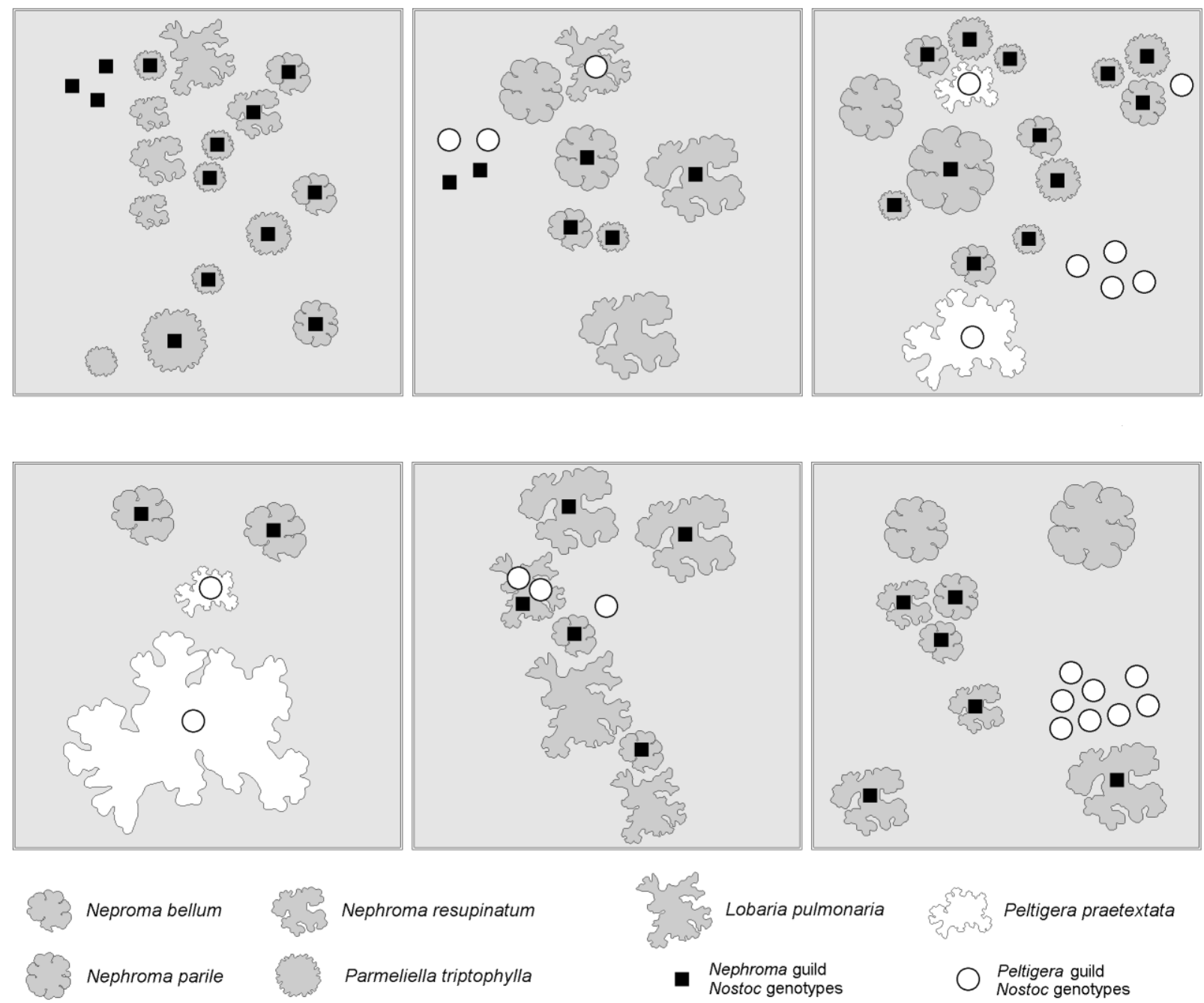

Figure 8. Distribution of symbiotic Nostoc strains on 6 tree trunk sample plots in two old-growth forests of central Finland. The cyanobionts of Nephroma bellum, N. parile, N. resupinatum, and Parmeliella triptophylla belong to four closely related tRNA ${ }^{\text {Leu }}$ (UAA) intron genotypes (solid symbols). These epiphytes exploit a common pool of cyanobionts and thus form a horizontally linked 'Nephroma guild'. The cyanobionts of Peltigera praetextata and most free-living Nostoc strains constitute a genetically more variable 'Peltigera guild' (open symbols). From Rikkinen, Oksanen and Lohtander, (unpublished results).

In a recent phylogenetic study of Peltigera, Miadlikowska and Lutzoni (2000) found that the cephalodiate species $P$. venosa, occupied a basal position within the genus. The other tripartite species belonged to two distinct paraphyletic groups that were nested within the bipartite species. Accordingly, the cephalodiate taxa were divided into three sections. $P$. venosa is easily distinguished form all other Peltigera species. In view of the above and on the basis of its unique chemistry and morphology, Miadlikowska and Lutzoni (2000) placed $P$. venosa in the monotypic section Phlebia. P. venosa has Nostoc cyanobionts in external cephalodia on the lower surface of the thallus. In addition, it regularly produces free-living cyanomorphs with homoiomerous, Leptogium-like thalli (Ott, 1988; Paulsrud et al., 2000). All other tripartite Peltigera species produce external cephalodia on their upper surface. Two such species, $P$. aphthosa and $P$. britannica, together with some bipartite species (e.g., P. malacea), belong to sect. 
Peltidea. The tripartite species are able to form photosymbiodemes, but these are not nearly as common as in $P$. venosa. When produced, the cyanomorphs are more or less identical with bipartite species of the section, but generally show poor fitness in natural environments. Finally, the third group of Peltigera with tripartite species, sect. Chloropeltigera, only includes cephalodiate taxa. These species are not known to produce photosymbiodemes in nature (Miadlikowska and Lutzoni, 2000).

Within Nephroma, a sister group of Peltigera, the tripartite species house typical 'Peltigera guild' Nostoc strains, while all bipartite species have typical 'Nephroma guild' cyanobionts. This segregation is quite significant as, like in Peltigera, the tripartite taxa do not form a monophyletic group. Conversely, some cephalodiate taxa are more closely related to bipartite species than to each other. This implies that within Nephroma, evolutionary transitions between bi- and tri-partite symbioses could not have been occurred simply via the acquisition or loss of the green algal photobiont; they would have also required concurrent switches in cyanobiont composition (Lohtander, Oksanen and Rikkinen, unpublished results). This may explain the poor fitness of many Nephroma cyanomorphs: the bipartite thalli appear to have lost their green algal symbionts but may still continue to house 'wrong' cyanobionts.

The cyanobionts of all Peltigera species belong to the same main group of symbiotic Nostoc strains (Lohtander, Oksanen and Rikkinen, unpublished results). However, this group is quite diverse and there are major differences in the cyanobiont spectra of individual Peltigera species. For example, $P$. venosa has exhibited a higher level of cyanobiont diversity than any other lichen species studied so far. Conversely, only two different Nostoc strains have been found from both P. aphthosa and P. britannica (Paulsrud and Lindblad, 1998; Paulsrud et al., 1998, 2000, 2001). This indicates that there may be a stepwise increase in cyanobiont specificity from sect. Phlebia to Peltidea, and finally to Chloropeltigera. This could, in turn, explain some group specific differences in the establishment of cephalodia and in the tendency to produce photosymbiodemes.

Stöcker-Wörgötter and Türk (1994) resynthesized $P$. leucophlebia in culture. This tripartite lichen belongs to sect. Chloropeltigera and thus does not produce photosymbiodemes in nature. However, four different types of thallus primordia developed in culture: primordia containing Nostoc, primordia containing Coccomyxa, primordia containing both photobionts, and cyanobacterial lobules with green algal outgrowths. The primordia with both photobionts soon died and the primordia with Nostoc did not differentiate into heteromerous thalli. Eventually the cultures were dominated by small P. leucophlebia chlorotypes arising from a layer of Nostoc. Quite remarkably, the final establishment of cephalodia did not occur through the capture of free-living cyanobacteria by the chlorotypes: only previously lichenized cyanobacterial primordia were attached to the green algal thalli. Colonies of free-living Nostoc were even purposely inoculated on the thallus surface, but these were not incorporated into cephalodia (Stöcker-Wörgötter and Türk, 1994). These results were in clear contrast with many previous and later reports of cephalodia being generated through the capture of free-living Nostocs by cortical hyphae or by rhizines (Jordan, 1970; Jordan and Rickson, 1971; Jahns, 1988; Lehr et al., 2000). However, the later group of observations had been made from $P$. aphthosa or other lichens that are not closely related to $P$. leucophlebia. Clearly, several mechanisms of cephalodial establishment might exist among different groups of tripartite lichens.

It is tempting to speculate that $P$. venosa has many features that once characterized the ancestor of modern Peltigera species and probably also the common ancestor of Peltigera and Nephroma. These include the ability to 
form associations with many types of Nostoc and the ability to produce different morphotypes, including both tripartite and bipartite thalli. Furthermore, it seems quite possible that some extant continuums between bipartite and cephalodiate cyanolichens could reflect genetic polymorphism within the fungal components of these symbioses. Nobody has shown that the cyanobacterial and green algal morphotypes would, in fact, represent different genets of the same mycobiont species, showing different photobiont preferences. However, as the mating of many lichenforming fungi is likely to require the fusion of propagules with previously established thalli, and as the cephalodial establishment of some tripartite lichens seems to require previously lichenized propagules, there might be a direct link between sexual processes and the early evolution of cephalodia. These processes, that are readily visible in tripartite cyanolichens, might also occur in many bipartite lichens. In these types of symbioses the fusion of sexual or symbiotic propagules with established thalli could play its original role in fungal reproduction. In some cephalodiate lichens this process may have acquired a secondary role in keeping a compatible cyanobiont within the symbiotic consortium.

\section{EVOLUTION OF CYANOLICHENS}

Cyanobacteria, plants and fungi have affected each other profoundly during the course of evolution. The ultimate examples of this are the plastids of eukaryotic algae and plants which once evolved from cyanobacterial ancestors. Furthermore, it seems quite likely that the initial diversification of terrestrial biota was closely linked to the appearance of lichen-like and mycorrhizal symbioses, the two major types of mutualistic interactions between photosynthetic organisms and fungi. The oldest fossil accounts of both occur in the Early Devonian over 400 million years ago (Taylor and Taylor, 1993; Taylor et al., 1997). However, both types of symbioses may have evolved much earlier, deep within the Precambrian. Cyanobacteria are an ancient group of organisms and recent molecular clock estimates have indicated that all major lineages of extant Fungi were already present at least 1000 million years ago. These estimates have also indicated that land plants appeared by $700 \mathrm{Ma}$ (Heckman et al., 2001).

\subsection{Evidence of Antiquity}

The degree of mutual dependence of symbiotic partners may often correlate with the evolutionary age of the association. Almost all lichen mycobionts are obligately lichen-forming and many of them seem to be unable to complete their normal life-cycles in the aposymbiotic state. This feature is particularly pronounced among the mycobionts of cyanolichens. For example, in a recent study Crittenden et al. (1995) attempted to isolate and bring into pure culture over 1000 species of lichen-forming and lichenicolous fungi from diverse ecosystems and systematic groups. Almost 500 species were successfully isolated from spores or from thallus macerates. However, only $22 \%$ of cyanobacterial lichens yielded fungal isolates compared with $46 \%$ and $43 \%$ of those containing chlorococcoid and trentepohlioid green algae, respectively. Success with bipartite cyanolichens was particularly low; less than $10 \%$ of studied species in the Pannariaceae and Collemataceae, for example, yielded fungal isolates (Crittenden et al., 1995). 
Most lichen-forming fungi depend on trebouxioid green algae. Species of Trebouxia are more or less confined to lichens and they seem to have given up much of their individual lives. Some of them may depend on their fungal partners to such an extent that they are poorly equipped for independent existence in natural environments (Rikkinen, 1995). Conversely, many cyanobacteria, including symbiotic forms, seem to have remained more or less unchanged since the Precambrian. Upon isolation and culture they easily revert to a typical free-living form. However, the fact that some lichen-forming Nostoc strains do not readily produce hormogonia in culture might reflect an adaptation to symbiotic dispersal (Paulsrud et al., 2001).

Despite the lack of obvious morphological adaptations to a symbiotic lifestyle, cyanobacteria most probably were already involved in the earliest lichen-like symbioses. Green and Lange (1994) suggested that such lichens could have been early colonizers of terrestrial habitats, their prime adaptation being the capacity to tolerate desiccation. Also the adaptive significance of the lichen thallus as a shield against UV radiation may have been important in promoting the early colonization of terrestrial habitats (Rikkinen, 1995). The dual ability to produce photosynthate and to fix atmospheric nitrogen was, of course, the central factor in promoting the early recruitment of cyanobacteria into lichen-like symbioses.

\subsection{Fossil Lichens}

Lichens are unlikely candidates for fossilization and thus few well preserved lichen fossils have ever been found. As pointed out by Green and Lange (1994) problems of fossilization are probably the most important reason for the scarcity of lichens in the fossil record. Fossil assemblages are indeed notorious for their many biases; most notably for the unequal preservation of hard and soft structures.

Taylor et al. (1997) described an exquisitely preserved cyanolichen from the 400 million-year-old Rhynie chert. The same paleoecosystem has also provided important information on many other types of fungal organisms (Taylor and Taylor, 1993, 1997; Taylor, 1994; Hass et al., 1994; Taylor et al., 1992, 1999). Specimens of the fossilized lichen consist of a thallus of superimposed layers of aseptate hyphae and, on the upper surface, numerous depressions. Extending into the bases of the depressions are fungal hyphae that form a three-dimensional netlike structure. Enclosed within the net are coccoid cyanobacteria. The cyanobacterial cells have thick sheaths and some of them have divided in three planes, resulting in colonial clusters. Old cells are parasitized by the fungus in the base of the hyphal net, while new cyanobacterial cells are formed distally. This results in the production of soredia-like symbiotic propagules (Taylor et al., 1997).

The Early Devonian lichen was placed into the new genus Winfrenatia and the authors suggested that its fungal component could have been an early zygomycete (Taylor et al., 1997). The cyanobionts are quite similar to modern pleurocapsalean forms, like Chroococcidiopsis. While the non-septate hyphae and chlamydospores of the fossilized fungus support a zygomycetous affinity, the fossilized thallus also has many characteristics of some extant gelatinous ascomycetes. For example, species of Anema, Paulia and Phylliscum all house unicellular cyanobionts in loose networks of hyphae, quite similar to the hyphal nets of Winfrenatia. Also the habitat requirements of these lichens correspond with the environment postulated for the Rhynie chert paleoecosystem. Schultz et al. (1999) suggested 
that modern Paulia species would have already evolved on the continental center of Pangaea. Thus, their present widely disjunct distributions would mainly reflect the effects of continental drift.

Perfectly preserved amber fossils have shown that many modern lichen genera, and possibly even species, were already present in the Tertiary (Poinar and Poinar, 1999; Peterson, 2000; Poinar et al., 2000; Rikkinen and Poinar, unpublished results). For example, two fossil species of Parmelia s. lat. were recently described from Dominican amber and several other fossils are known from Mexican and Baltic ambers (Poinar et al., 2000; Rikkinen, unpublished results). For example, two well preserved specimens of the foliose green algal lichen Anzia were recently found from Baltic amber (Rikkinen and Poinar, unpublished results). The fossils show that all characteristics in the thallus morphology of Anzia sect. Anzia have remained unchanged for at least 40 million years. As there is no reason to believe that the fossilisation would have been immediately preceded by a period of more rapid evolution, the initial divergence of anzioid lichens must have happened in the distant past, probably in the Cretaceous. No amber fossils of cyanolichens have yet been described. However, a 12-24 million year old impression of a foliose species belonging to Lobariaceae was recently reported by Peterson (2000).

Even a single fossil has the potential to give a minimum age estimate for the origins of several evolutionary lineages. Eventually, after more detailed phylogenetic hypotheses have been generated for different groups of lichens, the few available fossils will become invaluable for timing branching events and calibrating molecular clocks (Parks and Wendel, 1990; Hibbett et al., 1997; Xiang et al., 1998; Taylor et al., 1999). Printzen and Lumbsch (2000) used vegetation history and paleoclimatic data to calibrate a molecular clock based on fungal ITS sequences from two genera of epiphytic green algal lichens. Their results indicated that diversification within Biatora started already in the Late Cretaceous and took place during periods of climate cooling, when many new forest vegetation types evolved and spread in the Northern Hemisphere.

Because lichen fossils are rare, most of what is presently known of lichen evolution is based on comparative studies of extant taxa. The proposed antiquity of many modern cyanolichens, like Paulia species, is supported by their present range. Some lichens show classic disjunct ranges involving East Asia and eastern North America. In the case of Anzia this distribution, together with the European amber fossils, clearly indicated that these lichens once had a circum-Laurasian range (Rikkinen and Poinar, 2000). Later they became extinct from Europe, but were preserved in East Asia and eastern North America. Both regions have acted as centres of survival for many groups of organisms that previously had a semi-continuous range across the Holarctic, but suffered major constrictions in range as a consequence of climatic deterioration during the Pleistocene. Thus, the present distributions of some lichens and fungi correspond with the relict ranges of gymnosperms, like Metasequoia and Ginkgo, and of angiosperms, like Liriodendron and Magnolia (Tiffney, 1985; Redhead, 1989; Galloway, 1994; Jørgensen, 1994, 2000; Wu and Mueller, 1997; Xiang et al., 1998; Rikkinen and Poinar, 2000; Wu et al., 2000).

\subsection{Possible Relations with Mycorrhizal Symbioses}

Cyanobacteria initially evolved oxygenic photosynthesis and so changed the Earth's atmosphere from anoxic to oxic. As a consequence, most nitrogen-fixing bacteria became confined to anoxic environmental niches. This is mainly because nitrogenase, the enzyme complex responsible for nitrogen fixation, is highly sensitive to oxygen. In the 
cyanobacteria several strategies evolved to protect nitrogenase from oxygen, including a temporal separation of oxygenic photosynthesis and nitrogen fixation or, in some filamentous groups, the differentiation of a specialized cell, the heterocyst, to protect the functioning of nitrogenase. However, this sensitivity may also have enhanced the evolution of cyanobacterial symbioses, as some symbiotic structures help to protect cyanobacterial cells from atmospheric oxygen.

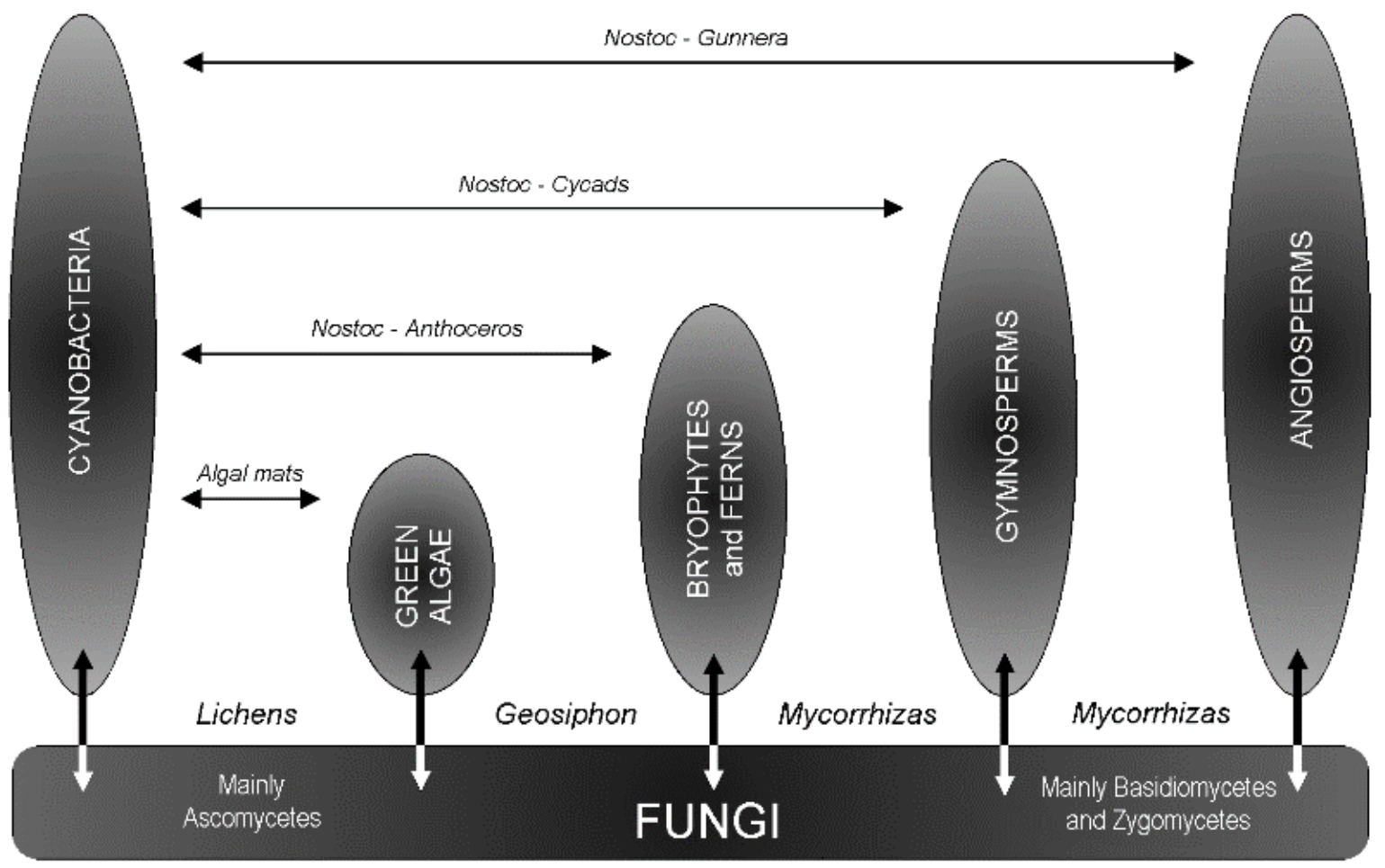

Figure 9. Mutualistic interactions between cyanobacteria, green plants and fungi. Symbiotic associations between cyanobacteria and fungi evolved before the initial evolution of mycorrhizal symbioses, the rise of vascular plants, and the subsequent diversification of parasitic and saprophytic fungi. Both lichens and mycorrhizal symbioses are polyphyletic and have evolved repeatedly. The diversification of mycorrhizal symbioses, in close associations with nitrogen-fixing soil bacteria, has reduced the relative importance of cyanobacterial symbioses during evolution. However, isolated representatives in all major groups of vascular plants can form stable symbioses with nitrogenfixing cyanobacteria.

The evolution of some cyanobacterial symbioses could even correlate temporally with geological periods of increased oxygen in the atmosphere. Especially during the Carboniferous high atmospheric oxygen concentrations (possibly over $30 \%$ ) might have seriously interfered with nitrogen-fixation. This would have given adaptive value to all structures and mechanisms that help to isolate nitrogen-fixing cells from the atmosphere. Hence the birth of some symbiotic structures, like the coralloid roots of cycads, might represent a parallel case to the development of arthropod and amphibian gigantism, which appear to have been directly facilitated by the hyperoxic atmosphere (Dudley-Robert, 1998). While the later phenomena, like many others, were subsequently lost during the late Permian 
transition to hypoxia, most types of cyanobacterial symbioses were not. Lower $\mathrm{O}_{2}$ concentrations did not directly threaten the symbiotic associations which continued to function under hypoxic condition as well. However, the ecological significance of cyanobacterial nitrogen fixation may have been greatly reduced when rhizosphere symbioses became a viable option for nitrogen starved plants.

The mycelia of mycorrhizal fungi are known to associate with soil bacteria capable of using organic nitrogen compounds and/or fixing atmospheric nitrogen (Perez-Moreno and Read, 2000; Sen, 2000). The early evolution of these associations is not known, but there may have been a real triumph of rhizosphere interactions in the late Permian, when free-living soil bacteria, following the atmospheric transition to hypoxia, became more efficient in nitrogen-fixation. This may have given a boost to the evolution of mycorrhizal symbioses and the subsequent diversification of vascular plants. Similar expansions soon followed in parasitic and saprophytic interactions between plants and fungi. Also the radiation of fungal endophytes and modern lichens must have been closely linked to the diversification of vascular plants. For example, most families of extant lichens include many epiphytic forms.

The earliest fungal symbioses may well have been primitive lichens, most probably those with cyanobacterial photobionts. Littoral habitats along ancient shore-lines brought a wide range of free-living cyanobacteria, green algae and fungi into close contact under conditions where there were good opportunities for the evolution of new symbiotic interactions (Rikkinen, 1995). The earliest lichens may have developed long before the initial evolution of mycorrhizal symbioses, the subsequent rise of vascular plants and the later diversification of parasitic and saprophytic fungi. Accordingly, some modern cyanolichens may preserve biological features from very early stages of terrestrial evolution.

Mutualistic and parasitic interactions between cyanobacteria, plants and fungi are clearly polyphyletic and have repeatedly evolved from each other during the course of evolution. The trend towards more versatile and efficient fungal and bacterial symbioses may have reduced the relative importance of cyanobacterial symbioses during fungal and vascular plant evolution. However, isolated representatives of all major groups of extant plants and fungi form associations with nitrogen-fixing cyanobacteria (Fig. 9). The closely intertwined evolutionary history of all these organisms indicates that there are many basic similarities in the molecular recognition systems of symbiotic cyanobacteria, green plants and fungi.

\section{REFERENCES}

Adams, D.G. (2000) Symbiotic interactions in Whitton, B.A. and Potts, M. (eds.), The Ecology of Cyanobacteria, Kluwer Academic Publishers, Dordrecht, pp. 523-561.

Ahmadjian, V. (1989) Studies on the isolation and synthesis of bionts of the cyanolichen Peltigera canina (Peltigeraceae), Plant Systemat. Evol. 165, 29-38.

Ahmadjian V. (1993) The Lichen Symbiosis, John Wiley and Sons, New York. Alexopoulos, C.J., Mims, C.W., and Blackwell, M. (1996) Introductory Mycology, John Wiley and Sons, USA. Alstrup, V. and Hawksworth, D.L. (1990) The lichenicolous fungi of Greenland. Meddelelser om Grønland, Bioscience 31, 1-90.

Aptroot, A. (1998) Aspects of the integration of the taxonomy of lichenized and non-lichenized pyrenocarpous ascomycetes, Lichenologist 30, 501-514.

Aptroot, A., Diederich, P., Sérusiaux, E. and Sipman, H.J.M. (1997) Lichens and lichenicolous fungi from New Guinea, 
Bibliotheca Lichenologica 64, 1-220.

Armaleo, D. and Clerc, P. (1991) Lichen chimeras: DNA analysis suggests that one fungus forms two morphotypes, Exp. Mycol. 15, 1-10.

Armaleo, D. and Miao, W. (1998) Symbiosis and DNA methylation in the Cladonia lichen fungus, Symbiosis 26, 143163.

Awasthi, D.D. (2000) A Handbook of Lichens, Bishen Singh Mahendrapal Singh, Dehradun, India.

Baron, G. (1999) Understanding Lichens, The Richmond Publishing Co. Ltd., Slough,UK.

Beck, A. (1999) Photobiont inventory of a lichen community growing on heavy metal-rich rock, Lichenologist 31, 501510.

Beck, A., Friedl, T., and Rambold, G. (1998) Selectivity of photobiont choice in a defined lichen community: inference from cultural and molecular studies, New Phytol. 13, 709-720.

Bergman, B. and Hällbom, L. (1982) Nostoc of Peltigera canina when lichenized and isolated, Can. J. Bot. 60, 20922098.

Bergman, B., Rai, A.N., Johansson, C. and Söderbäck, E. (1993) Cyanobacterial-plant symbioses, Symbiosis 14, 61-81. Brodo, I.M. and Richardson, D.H.S. (1979) Chimeroid associations in the genus Peltigera, Lichenologist 10, $157-170$.

Büdel, B. (1990) Anatomical adaptations to the semiarid/arid environment in the lichen genus Peltula, Bibliotheca Lichenologica 38, 47-61.

Büdel, B. (1992) Taxonomy of lichenized prokaryotic blue-green algae, in Reisser, W. (ed.), Alage and Symbioses, Biopress, Bristol, pp. 301-324.

Büdel, B. and Lange, O.L. (1991) Water status of green and blue-green phycobionts in lichen thalli after hydration by water vapour uptake: do they become turgid? Acta Botanica 104, 361-366.

Büdel, B. and Lange, O.L. (1994) The role of cortical and epinecral layers in the lichen genus Peltula, Cryptogam. Bot. 4, 262-269.

Büdel, B., Lüttge, U., Stelzer, R., Huber, O., and Medina, E. (1994) Cyanobacteria of rocks and soils of the Orinoco Lowlands and the Guayana Uplands, Venezuela, Acta Botanica 107, 422-431.

Büdel, B. and Scheidegger, C. (1996) Thallus morphology and anatomy, in Nash III, T.H. (ed.), Lichen Biology. Cambridge University Press, Cambridge, pp. 37-64.

Castenholz, R.W. (2001) Phylum BX. Cyanobacteria, in Garrity, G.M. (ed.), Bergey's Manual of Systematic Bacteorology Vol I, Springer-Verlag, Berlin, pp. 473-599.

Clauzade, G. and Roux, C. (1986) Likenoj de okcidenta Europa. Ilustrita determinlibro, Bull. Soc. Bot. Centre-Quest Novelle serie 7, 1-893.

Coppins, E., Debuchy, R., Arnaise, S., and Picard, M. (1997) Mating types and secual development in filamentous ascomycetes, Microbiol. Mol. Biol. Rev. 61, 411-428.

Crittenden, P.D., David, J.C., Hawksworth, D.L., and Campbell, F.S. (1995) Attempted isolation and success in the culturing of a broad spectrum of lichen-forming and lichenicolous fungi, New Phytol. 130, 267-297.

Culberson, C.F., Culberson, W.L. and Johnson, A. (1988) Gene flow in lichens, Amer. J. Bot. 75, 1135-1139.

Degelius, G. (1954). The lichen genus Collema in Europe, Symbolae Botanicae Upsalienses 13, 1-499.

Dellemère, A. (1994) Asci and ascospores in ascomycete systematics, in Hawksworth, D.L . (ed.), Ascomycete Systematics: Problems and Perspectives in the Nineties, Plenum Press, New York, pp. 111-126.

Demmig-Adams, B., Adams III, W.W., Green, T.G.A., Czygan, F.C. and Lange, O.L. (1990) Differences in the susceptibility to light stress in two lichens forming a phycosymbiodeme, one partner possessing and one lacking the xanthophyll cycle, Oecologia 84, 451-456.

Dietz, S., Büdel, B., Lange, O.L., and Bilger, W. (2000) Transmittance of light through the cortex of lichens from contrasting habitats, Bibliotheca Lichenologica 75, 171-182.

Dudley-Robert (1998) Atmospheric oxygen, giant palaeozoic insects and the evolution of aerial locomotor performance, J. Exp. Biol. 201, 1043-1050.

Eldridge, D. and Tozer, M.E. (1997) A Practical Guide to Soil Lichens and Bryophytes of Australia's Dry Country, New South Wales Department of Land and Water Conservation, Australia.

Etges, S. and Ott, S. (2001) Lichen mycobionts transplanted into the natural habitat, Symbiosis 30, 191-206.

Forssel, K.B.J. (1883) Studier öfver cephalodierna. Bidrag till kännedomen om lafvarnes anatomi och utvecklingshistoria, Bihang till Kongliga Svenska Vetensaps. Akaemiens Handlingar 8, 1-112.

Friedl, T. (1995) Inferring taxonomic positions and testing genus level assignments in coccoid green algae; a phylogenetic analysis of $18 \mathrm{~S}$ ribosomal RNA sequences from Dictyochloropsis reticulata and form members of the genus Myrmecia (Chlorophyta, Trebouxiophyceae cl. nov.), J. Phycol. 31, 632-639.

Friedl, T. and Büdel, B. (1996) Photobionts, in Nash III, T. H. (ed.), Lichen Biology, Cambridge University Press, 
Cambridge, pp. 8-23.

Friedl, T. and Rokitta, C. (1997) Species relationships in the lichen alga Trebouxia (Chlorophyta, Trebouxiophyceae): Molecular phylogenetic analyses of nuclear-encoded large subunit rRNA gene sequences, Symbiosis 23, 125-148.

Galloway, D.J. (1994) Biogeography and ancestry of lichens and other ascomycetes, in Hawksworth, D.L. (ed.), Ascomycete Systematics: Problems and Perspectives in the Nineties, Plenum Press, New York, pp. 175-184.

Galun, M. and Peleg-Zuriel, L. (2000) Growth enhancement of lichen-forming fungi, Bibliotheca Lichenologica 75, 105111.

Gargas, A., DePriest, P.T., Grube, M. and Tehler, A. (1995) Multiple origins of lichen symbioses in Fungi suggested by SSU rDNA phylogeny, Science 268, 1492-1495.

Gassmann A. and Ott, S. (2000) Growth-strategy and the gradual symbiotic interactions of the lichen Ochrolechia frigida, Plant Biology 2, 368-378.

Geitler, L. (1932) Cyanophyceae, in Kolkwitz (ed.), Kryptogamenflora von Deutschland, Österreich und der Schweiz Vol. 14, Akademische Verlagsgesellschaft, Leipzig, pp. 1-1196.

Girlanda, M., Isocrono, D., Bianco, C., and Luppi-Mosca, A.M. (1997) Two foliose lichens as microfungal ecological niches, Mycologia 89, 531-536.

Glass, N.L. and Kuldau, G.A. (1992) Mating type and vegetative incompatibility in filamentous ascomycetes., Annu. Rev. Phytopathol. 30, 201-224.

Goffinet, B. and Bayer R.J. (1997) Characterization of mycobionts of phytomorph pairs in the Peltigerineae (lichenized ascomycetes) based on internal transcribed spacer sequences of the nuclear ribosomal DNA, Fungal Genetic. Biol. 21, 228-237.

Goffinet, B. and Hastings, R.I. (1995) Two new sorediate taxa of Peltigera. Lichenologist 27, 43-58.

Goward, T. (1999) The Lichens of British Columbia, Illustrated Keys Part 2, Fruticose Species, Ministry of Forests (Research Branch), Victoria, Canada.

Goward, T. and Goffinet, B. (1998) Is Nephroma silvae-veteris the cyanomorphs of Lobaria oregana? Insights from molecular, chemical and morphological characters, in Glenn, M.G., Harris, R.C., Dirig, R. and Cole, M.S. (eds.), Lichenographia Thomsoniana: North American Lichenology in Honour of John W. Thompson, Mycotaxon Ltd, Ithaca, pp. 41-52.

Goward, T., McCune, B. and Meidinger, D. (1994) The Lichens of British Columbia, Illustrated Keys Part 1, Foliose and Squamulose Species, Ministry of Forests (Research Branch), Victoria, Canada.

Green, T.G.A., Büdel, B., Heber, U., Meyer, A., Zellner, H., and Lange O.L. (1993) Differences in photosynthetic performance between cyanobacterial and green algal components of lichen photosymbiodemes measured in the field, New Phytol 125, 723-731.

Green, T.G.A. and Lange, O.L. (1994) Photosynthesis in poikilohydric plants: a comparison of lichens and bryophytes. in Schulze, E.D. and Caldwell, M.C. (eds.), Ecophysiology of Photosynthesis, Springer-Verlag, Berlin., pp. 319-341.

Haffellner, J., Hertel, H., Rambold, G. and Timdal, E. (1994) Discussion 4: Lecanorales, in Hawksworth, D.L. (ed.), Ascomycete Systematics: Problems and Perspectives in the Nineties, Plenum Press, New York, pp. 379-397.

Hass, H., Taylor, T.N. and Remy, W. (1994) Fungi from the Lower Devonian Rhynie chert: mycoparatism, Amer. J. Bot. 81, 29-37.

Hawksworth, D. L. (1988) The variety of fungal-algal symbioses, their evolutionary significance, and the nature of lichens, Bot. J. Linn. Soc. 96, 3-20.

Hawksworth, D.L. and Miadlikowska, J. (1997) New species of lichenicolous fungi occurring on Peltigera in Ecuador and Europe, Mycol. Res. 101, 1127-1134.

Hawksworth, D.L., Kirk, P.M., Sutton, B.C. and Pegler, D.N. (1995) Ainsworth and Bisby's Dictionary of the Fungi, International Mycological Institute, Egham, UK.

Hawksworth, D.L. and Rossman, A.Y. (1997) Where are all the undescribed fungi? Phytopathology 87, 888-891.

Heckman, D.S., Geiser, D.M., Eidell, B.R., Stauffer, R.L., Kardos, N.L., and Hedges, S.B. (2001) Molecular evidence fot the early colonization of land by fungi and plants, Science 293, 1129-1133.

Henssen, A. (1963) Eine Revision der Flechtenfamilien Lichinaceae und Ephebaceae, Symbolae Botanicae Upsalienses 18, 1-123.

Henssen, A, Büdel, B., and Titze, A. (1987) Euopsis and Harpidium, genera of the Lichinaceae (Lichenes) with rostrate asci, Botanica Acta 1, 49-55.

Hibbett, D.S., Grimaldi, D. and Donoghue, M.J. (1997) Fossil mushrooms from Miocene and Cretaceous ambers and the evolution of homobasidiomycetes, Amer. J. Bot. 84, 981-991.

Hill, D.J. (1989) The control of cell cycle in microbial symbionts, New Phytol. 112, 175-184. 
Hill, D.J. (1993) The co-ordination of development of symbionts in mutualistic symbiosis with reference to the cell cycle of the photobiont in lichens, Symbiosis 14, 325-333.

Honegger, R. (1991) Fungal evolution: symbiosis and morphogenesis, in Margulis, L. and Fester, R. (eds.), Symbiosis as a Source of Evolutionary Innovation, The MIT Press, Cambridge, pp. 319-340.

Honegger, R. (1997) Metabolic interactions at the mycobiont-photobiont interface in lichens, in Carroll, G.C. and Tudzynski, P. (eds.), The Mycota V Part A. Plant Relationships, Springer-Verlag, Berlin, pp. 209-221.

Honegger, R. and Hugelshofer, G. (2000) Water relations in the Peltigera aphthosa group visualised with LTSEM techniques. Bibliotheca Lichenologica 75, 113-126.

Huneck, S. and Yoshimura, I. (1996) Identification of Lichen Substances, Springer-Verlag, Heidelberg.

Jahns, H.M. (1973) Anatomy, morphology and development, in Ahmadjian, V. and Hale, Jr. M.E. (eds.), The Lichens, Academic Press, New York, pp. 3-58.

Jahns, H.M. (1988) The lichen thallus, in Galun, M. (ed), CRC Handbook of Lichenology, CRC Press Inc, Boca Raton, pp. 3-16.

Jahns, H.M. and Ott, S. (1997) Life strategies in lichens - some general considerations, Bibliotheca Lichenologica 67, 49-67.

James, P.W. and Henssen, A. (1976) The morphological and taxonomic significance of cephalodia, in Brown, D.H., Hawksworth, D.L. and Bailey, R.H. (eds.), Lichenology, Progress and Problems, Academic Press, London, pp. $27-77$. Jordan, W.P. (1970) The internal cephalodia of the genus Lobaria, Bryologist 73, 669-681.

Jordan, W.P. (1972) Erumpent cephalodia, an apparent case of phycobial influence on lichen morphology, J. Phycol. 8, 112-117.

Jordan, W.P. and Rickson, R. (1971) Cyanophyte cephalodia in the lichen genus Nephroma, Amer. J. Bot. 58, 562-568. Jørgensen, P.M. (1994) On the nomenclature of lichen phototypes, Taxon 45, 663-664.

Jørgensen, P.M. (1997) Lichen phototypes, nature's unmanageable misprints? Taxon 46, 721-722.

Jørgensen, P.M. (1998) What shall we do with the blue-green counterparts? Lichenologist 30, 351-356.

Jørgensen, P.M. (2000) Survey of the lichen family Pannariaceae on the American continent, north of Mexico, The Bryologist 103, 670-704.

Jørgensen, P.M. and Wedin, M. (1998) On Psoroma species from the Southern Hemisphere with cephalodia producing vegetative dispersal units, Lichenologist 31, 341-347.

Kantivilas, G. and Jarman, S.J. (1999) Lichens of Rainforest in Tasmania and South-Eastern Australia. The Australian Biological Resource Study, Canberra, Australia.

Kardish, N., Kessel, M. and Galun, M. (1989) Characterization of symbiotic and cultured Nostoc of the lichen Nephroma laevigatum Ach, Symbiosis 7, 257-266.

Kardish, N., Rotem-Abarbanell, D., Ziberstein, A. and Galun, M. (1990) Comparison between the symbiotic Nostoc of the lichen Nephroma laevigatum Ach. and its cultured, isolated Nostoc by recombination DNA, Symbiosis 8, 135145.

Karling, J.S. (1977) Chytridiomycetarium Iconographia, J. Cramer, Vaduz.

Komárek, J., Anagnostidis, K. (1989) Modern approach to the classification system of cyanophytes 4, Nostocales, Arch. Hydrobiol. Suppl. 82, 247-345.

Kondratyuk, S. and Galloway, D.J. (1995) Lichenicolous fungi and chemical patterns in Pseudocyphellaria, Bibliotheca Lichenologica 57, 327-345.

Kranner, I. and Lutzoni, F. (1999) Evolutionary consequences of transition to a lichen symbiotic state and physiological adaptation to oxidative damage associated with poikilohydry, in Lerner, H.R. (ed.), Plant Responces to Environmental Stresses: From Phytohormones to Genome Reorganization, Marcel Deccer, New York, pp. 591-628.

Kroken, S. and Taylor, J.W. (2000) Phylogenetic species, reproductive mode, and specificity of the green alga Trebouxia forming lichens with the fungal genus Letharia, The Bryologist 103, 645-660.

Lamb, I.M. (1951) On the morphology, phylogeny, and taxonomy of the lichen genus Stereocaulon, Can. J. Bot. 29, 522-584.

Lamb, I.M. (1968) The species of Stereocaulon with protosacculate cephalodia, Japan. J. Bot. 43, 291-301.

Lamb, I.M. (1976) Structurally unusual types of cephalodia in the lichen genus Stereocaulon (subgen. Holostedium), Japan. J. Bot 51, 353-359.

Lange, O.L., Kilian, E. and Ziegler, H. (1986) Water vapor uptake and photosynthesis in lichens: performance differences in species with green and blue-green algae as phycobionts, Oecologia 71, 104-110.

Lange, O.L., Bilger, W. And Schreiber, U. (1989) Chlorophyll fluorescence of lichens containing green and blue-green algae during hydration by water vapour uptake and by addition of liquid water, Botanica. Acta 102, 306-313.

Larson, D.W. and Carey, C.K. (1986) Phenotype variation within 'individual' lichen thalli, Amer. J. Bot. 73, $214-223$. 
Lehr, H., Fleminger, G. and Galun, M. (1995) Lectin from the lichen Peltigera membranacea (Ach.) Nyl.: characterization and function, Symbiosis 18, 1-13.

Lehr, H., Galun, M., Ott, S., Jahns, H.M. and Fleminger, G. (2000) Cephalodia of the lichen Peltigera aphthosa (L.) Willd. Specific recognition of the compatible photobiont, Symbiosis 29, 357-365.

Leslie, J.F. (1993) Fungal vegetative incompatibility, Annu. Rev. Phytopathol. 31, 127-150.

Letrouit-Galinou, M.A. and Asta, J. (1994) Thallus morphogenesis in some lichens, Cryptogam. Bot. 4, $274-282$.

Lutzoni, F., Pagel, M. and Reeb, V. (2001) Major fungal lineages are derived from lichen symbiotic ancestors, Nature 411, 937-940.

McCune, B. (1993) Gradients in the epiphyte biomass in three Pseudotsuga-Tsuga forests of different ages in Western Oregon and Washington, Bryologist 96, 405-411.

McCune, B. and Geiser, L. (1997) Macrolichens of the Pacific Northwest, Oregon State University Press, Corvallis.

Meeks, J.C., Campbell, E., Hagen K., Hanson, T., Hitzeman, N. and Wong, F. (1999) Developmental alternatives of symbiotic Nostoc punctiforme in response to its plant partner Anthoceros punctatus, in Peschek, G.A., Loffelhardt, W. and Schmetterer, G. (eds.), The Photosynthetic Prokaryotes, Kluwer Academic Publishers, pp. 665-678.

Miadlikowska; J. and Lutzoni, F. (2000) Phylogenetic revision of the genus Peltigera (lichen-forming Ascomycota) based on morphological, chemical, and large subunit nuclear ribosomal DNA data, Internat. J. Plant Sci. 16, 925958.

Miao, V.P.W., Rabenau, A. and Lee, A. (1997) Cultural and molecular characterization of photobionts of Peltigera membranacea, Lichenologist 29, 571-586.

Murthach, G.J., Dyer, P.S. and Crittenden, P. D. (2000) Reproductive systems: Sex and the single lichen, Nature 404, 564.

Nash III, T.H. (1996) Lichen Biology, Cambridge University Press, Cambridge.

Oberwinkler, F. (1984) Fungus-alga interactions in basidiolichens, Nova Hedwigia 79, 739-774.

Ott, S. (1993) Experimental research in regulation of developmental processes in lichens, in Abstracts of the XV International Botanical Congress, Yokohama, Japan.

Ott, S. (1988) Photosymbiodemes and their development in Peltigera venosa, Lichenologist 20, 361-368.

Ott, S. (1987) Sexual reproduction and developmental adaptations in Xanthoria parietina, Nordic J. Bot. 7, $219-228$.

Parks, C.R. and Wendel, J.F. (1990) Molecular divergence between Asian and North American species of Liriodendron (Magnoliaceae) with implications for interpretation of fossil floras, Amer. J. Bot. 77, 1243-1256.

Paulsrud, P. (2001) The Nostoc symbiont of lichens. Diversity, specificity and cellular modifications, Acta Universitatis Upsaliensis Comprehensive Summaries of Uppsala Dissertations from the Faculty of Science and Technology 662, 155.

Paulsrud, P. and Lindblad, P. (1998) Sequence variation of the tRNALeu intron as a marker for genetic diversity and specificity of symbiotic cyanobacteria in some lichens, Appl. Environ. Microbiol. 64, 310-315.

Paulsrud, P. Rikkinen, J. and Lindblad, P. (1998) Cyanobiont specificity in some Nostoc-containing lichens and in a Peltigera aphthosa photosymbiodeme, New Phytol. 139, 517-524.

Paulsrud, P., Rikkinen, J. and Lindblad, P. (2000) Spatial patterns of photobiont diversity in some Nostoc-containing lichens, New Phytol. 146, 291-299.

Paulsrud, P., Rikkinen, J. and Lindblad, P. (2001) Field experiments on cyanobacterial specificity in Peltigera aphthosa, New Phytol. 152, 117-123.

Perez-Moreno, J. and Read, D.J. (2000) Mobilization and transfer of nutrients from litter to tree seedlings via the vegetative mycelium of ectomycorrhizaö plants, New Phytol. 145, 301-309.

Peterson, E.B. (2000) An overlooked fossil lichen (Lobariaceae), Lichenologist 32, 298-300.

Petrini, O., Hake, U. and Dreyfuss, M. (1990) Analysis of fungal communities isolated from fruticose lichens, Mycologia 82, 444-451.

Peveling, E. (1988) Beziehungen zwischen den Symbiosepartnern in Flecten, Naturwissenschaften 75, 77-86.

Poelt, J. and Mayhofer, H. (1987) Über Cyanotrophie bei Flechten, Plant Systemat. Evol. 158, 265-281.

Poinar, Jr., G. and Poinar, R. (1999) The Amber Forest, Princeton University Press, Princeton.

Poinar, Jr., G., Peterson, E.B. and Platt, J.L. (2000) Fossil Parmelia in New World amber, Lichenologist 32, $263-269$.

Printzen, C. and Lumbsch, T. (2000) Molecular evidence for the diversification of extant lichens in the Late Cretaceous and Tertiary, Mol. Phylogenet. Evol. 17, 379-387.

Purvis, W. (2000) Lichens, Smithsonian Institute Press and Natural History Museum, London.

Rai, A.N., Söderback, E. and Bergman, B. (2000) Cyanobacterium-plant symbioses, New Phytol. 147, 449-481.

Rambold, G., Friedl, T., and Beck, A. (1998) Photobionts in lichens: possible indicators of phylogenetic relationships? The Bryologist 101, 392-397. 
Rambold, G. and Triebel, D. (1992) The inter-lecanoralean associations, Bibliotheca Lichenologica 48,1-201.

Raven, J.A. (1993) Energy and nutrient acquisition by autotrophic symbioses and their asymbiotic ancestors, Symbiosis 14, 33-60.

Redhead, S.A. (1989) A biogeographical overview of the Canadian mushroom flora, Can. J. Bot. 67, 3003-3062.

Richardson, D.H.S. (1999) War in the world of lichens: parasitism and symbiosis as exemplified by lichens and lichenicolous fungi, Mycol. Res. 103, 641-650.

Rikkinen, J. (1995) What's behind the pretty colours? A study on the photobiology of lichens, Bryobrothera 4, 1-239.

Rikkinen, J. (1997) Habitat shifts and morphological variation of Pseudevernia furfuracea along a topographic gradient, Symbolae Botanicae Upsalienses 32, 223-245.

Rikkinen, J. and Poinar, Jr., G. (2000) A new species of resinicolous Chaenothecopsis (Mycocaliciaceae, Ascomycota) from 20 million year old Bitterfeld amber, with remarks on the biology of resinicolous fungi, Mycol. Res. 104, 7-15.

Rippka, R., Deruelles, J., Waterbury, J.B., Herdman, M. and Stanier, R.Y. (1979) Generic assignements, strain histories and properties of pure cultures of cyanobacteria, J. Gen. Microbiol. 111, 1-61.

Round, F.E. (1984) The Ecology of Algae, Cambridge University Press, Cambridge.

Scheidegger, C. (1994) Low-temperature scanning electron microscopy: the localization of free and preturbed water and its role in the morpholgy of the lichen symbionts, Cryptogam. Bot. 4, 290-299.

Schelensog, M. Schroeter, B., and Green, T.G.A. (2000) Water dependent photosynthetic activity of lichens from New Zealand: differences in the green algal and the cyanobacterial thallus parts of photosymbiodemes, Bibliotheca Lichenologica 75, 149-160.

Schultz, M., Brown, G., and Büdel, B. (2000) Cyanophilous lichens from Kuwait, Nova Hedwigia 70,193-216.

Schultz, M., Mies, B. and Al-Gifri, A.N. (1999) New localities of some Paulia species (Lichinaceae, lichenized Ascomycota) from Socotra (Indian Ocean), Bryologist 102, 61-66.

Sen, R. (2000) Budgeting for the wood-wide web, New Phytol. 145, 161-165.

Sparrow, Jr., F.K. (1960) Aquatic Phycomycetes, The University of Michigan Press, Ann Arbor.

Socker-Wörgötter, E. (2001a) Experimental studies of the lichen symbiosis: DNA-analyses, differentiation and secondary chemistry of selected mycobionts, artificial resynthesis of two- and tripartite symbioses, Symbiosis 30, 207-227.

Stocker-Wörgötter, E. (2001b) Experimental lichenology and microbiology of lichens: culture experiments, secondary chemistry of cultured mycobionts, resynthesis, and thallus morphogenesis, Bryologist 104, 576-581.

Stocker-Wörgötter, E. and Türk, R. (1994) Artificial resynthesis of the photosymbiodeme Peltigera leucophlebia under laboratory conditions, Cryptogam. Bot. 4, 300-308.

Taylor, T.N. (1994) The fossil history of ascomycetes, in Hawksworth, D.L . (ed.), Ascomycete Systematics: Problems and Perspectives in the Nineties, Plenum Press, New York, pp. 167-174.

Taylor, T.N. and Taylor, E.L. (1993) The Biology and Evolution of Fossil Plants, Prentice Hall, Englewood Cliffs, New Jersey.

Taylor, T.N. and Taylor, E.L. (1997) The distributions and interactions of some Paleozoic fungi, Rev. Palaeobot. Palynol. 95, 83-94.

Taylor, T.N., Hass, H. and Kerp, H. (1997) A cyanolichen from the Lower Devonian Rhynie chert, Amer. J. Bot. 84, 9921004.

Taylor, T.N., Hass, H. and Kerp, H. (1999) The oldest fossil ascomycetes, Nature 399, 648.

Taylor, T.N., Remy, W. and Hass, H. (1992) Fungi from the Lower Devonian Rhynie chert: chytridiomycetes, Amer. J. Bot. 79, 1233-1241.

Tehler, A. (1996) Systematics, phylogeny and classification, in Nash III, T. H. (ed.), Lichen Biology, Cambridge University Press, Cambridge, pp. 217-239.

Tehler, A., Farris, J.S., Lipscomb, D.L. and Källersjö, M. (2000) Phylogenetic analyses of the fungi based on large rDNA data sets, Mycologia 92, 459-474.

Tiffney, B.H. (1985) Perspectives of the origin of the floristic similarity between eastern Asia and eastern North America, J. Arnold Arboretum 66, 73-94.

Tønsberg, T. and Goward, T. (2001) Sticta oroborealis sp.nov. and other Pacific North American lichens forming dendriscocauloid cyanotypes, Bryologist 104, 12-23.

Tønsberg, T. and Holtan-Hartwig, J. (1983) Phycotype pairs in Nephroma, Peltigera and Lobaria in Norway, Nordic J. Bot. 3, 681-688.

Tschermak-Woess E. (1988) The algal partner, in Galun, M. (ed.), CRC Handbook of Lichenology Vol. I, CRC Press, Boca Raton, pp. 39-92. 
Tschermak-Woess E. (1995) The taxonomic position of the green phycobiont of Sticta canariensis (Ach.) Bory ex Delise and its extraordinary modification in the lichenized state, Bibliotheca Lichenologica 58, 433-438.

Vitikainen, O. (1994) Taxonomic revision of Peltigera (lichenized Ascomycotina) in Europe, Acta Botanica Fennica 152, 1-96.

Wirth, V. (1980) Flectenflora, Verlag Eugen Ulmer, Stuttgart.

Wirth, V. (1995) Die Flecten Baden-Wurttenbergs, Verlag Eugen Ulmer, Stuttgart.

Wu, Q.X. and Mueller, G.M. (1997) Biogeographic relationships between macrofungi of temperate eastern Asia and eastern North America, Can. J. Bot. 75, 2108-2116.

Wu, Q.X., Mueller, G.M., Lutzoni, F.M., Huang, Y.Q. and Guo, S.Y. (2000) Phylogenetic and biogeographic relationships of eastern Asian and eastern North American disjunct Suillus species (Fungi) as inferred from nuclear ribosomal RNA ITS sequences, Mol. Phylogenet. Evol. 17, 37-47.

Xiang, Q.Y., Soltis, D.E. and Soltis, P.S. (1998) The eastern Asian and eastern and western North American floristic disjunction: congruent phylogenetic patterns in seven diverse genera, Mol. Phylogenet. Evol. 10, 178-190.

Yoshimura, I. and Yamamoto, Y. (1991) Development of Peltigera praetextata lichen thalli in culture, Symbiosis 11, 109-117.

Yoshimura, I., Kurokawa, T., Yamamoto, Y., and Kinoshita, Y. (1994) In vitro development of the lichen thallus of some species of Peltigera, Cryptogam. Bot. 4, 314-319. 